University of Louisville

ThinkIR: The University of Louisville's Institutional Repository

1944

\title{
Changing philosophy of child care in the Louisville and Jefferson County Children's Home, 1854-1943.
}

Helen Hardwicke Sherrill

University of Louisville

Follow this and additional works at: https://ir.library.louisville.edu/etd

Part of the Social Work Commons

\section{Recommended Citation}

Sherrill, Helen Hardwicke, "Changing philosophy of child care in the Louisville and Jefferson County Children's Home, 1854-1943." (1944). Electronic Theses and Dissertations. Paper 2172.

https://doi.org/10.18297/etd/2172

This Master's Thesis is brought to you for free and open access by ThinkIR: The University of Louisville's Institutional Repository. It has been accepted for inclusion in Electronic Theses and Dissertations by an authorized administrator of ThinkIR: The University of Louisville's Institutional Repository. This title appears here courtesy of the author, who has retained all other copyrights. For more information, please contact thinkir@louisville.edu. 


\title{
UNIVERSITY OF LOUISVILLE
}

\author{
CHANGIHG PHILOSOPHY OF CHILD CARE IN THE \\ LOUISVILLE AND JEPFERSON COUNTY \\ CHILDREN'S HOME (1854-1943)
}

\begin{abstract}
A D1ssertation
Submitted to the Faculty

of the Graduate Sohool of the Univergity of Louisvilie

In Partial Fulfiliment of the

Requirements for the Degree

or
\end{abstract}

Master of Sclence in Social Administration

Graduate Division of Social Administration

By

Helen Hardwicke Sherrill

1944 
NAME OP STUDENT: Helen Hardwicke Sherrill

PITLE OF THESIS: Changing Philosophy of

Child Care in the Loulspilie

and Jefferson County Chil-

dren's Home (1854-1943)

APPROVED BY READING COMMITIEE COMPOSED OF THE FOLLOWING MEMBERS :

John J. Cronin

Robert G. Warner

Annie Louise Pruitt

NAME OF DIRECTOR: John J. Cronin

DATE: $\quad 6 / 1 / 44$ 
AN ACKNOWLEDGEMENT

The writer wishes to acknowledge her gratitude to Mr. John J. Cronin for his direction and assistance in the preparation of this material; to Mr. Henley V. Bastin and the members of his staff for their con operation in helping place material at her disposal; to Miss Edna Graumen in the research department of the Loulsville Pree Public Library for her help in finding old records; and espeolally to her husband, Iewis Joseph Sherril1, without whose encouragement the goal would never have been reached. 
For every child who is in conflict with soclety the right to be dealt with intelligently as society's charge, not society's outcast; with the home, the school, the church, the court and the institution when needed, shaped to return him whenever possible to the normal stream or 11fe.

The Children's Charter, Section XIV 
TABLE OF CONTENTS

Introduction Page

Chapter

I. CHANGING AIMS AND METHODS OF CARING FOR DEPENDENT CHILDREN . . . . . . . . 4

II. CHANGES DUE TO INCREASING NEEDS FOR SERVICE TO CHILDREN IN LOUISVILLE AND JEFIERSON COUNTY .......... 21

III. CHANGING COMCEPTS OF CHIID CARE IN REGARD TO WORK AND SEPARATION OF DELINQUENTS AND DEPEIDENTS • • • • • 35

IV. CHANGING PHILOSOPHY IN REGARD TO DISCIPLINE AND RELATIONSHIP WITH PARENTS . . . . . . . . . . 57

V. EVALUATION OF THE WORK OF TPE LOUISVILLE AND JEFIERSON COUNTY

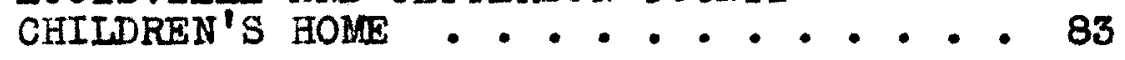


CHANGING PHILOSOPHY OF CHILD CARE IN THE LOUISVILLE AND JEFFERSON COUNTY CHILDREN'S HOME (1854-1943) 
INTRODUCTION 


\section{INTRODUCTION}

This study is an attempt to understand what Louisville and Jefferson county have done, and ought to try to do for and with dependent chlldren. The author proposes to trace the changing phllosophy in taxsupported care of delinquent, neglected, and dependent children in Louigville and Jefferson County since 1854, to dra some conclusions and make recommendations which may prove helpful in the future planning for such children.

Thorough studies of the Loulsvilie and Jefferson county Children's Home, evaluating 1ts work and suggesting changes in its program, have been made by such organizations as the Child Welfare League of America, the Rassell Sage Foundation and the Osborne Association. Th1s plece of work is not intended in any way to duplicate the kind of appraisal made by these authorities in the fleld. It is rather an attempt to trace the changes brought about in the institution by the increasing demands for such a service to children, and to note the changing philosophy of child care in relation to specific problems which are conmon to all institutions that have to deal with delinquent and dependent children. 
The time is ripening for such an advance as the world has never yet seen in the discovery and development of personality, happiness and capacity for social achlevement, not only in the dependent child but in every child. If wo gradualiy raise the level of our standards of care for dependent children, the standards of positive welfare of all children in families just above that level will also be ralsed. 1

In this study the author wishes to show how the standards of care for the dependent children in this community have been ralsed and to point toward some conclusions which may prove holpful in the future planning for such children.

The primary source of material has been the annual reports of the superintendent of the institution. These have been compared with the section on child welfare in the reports of the Conference of Charities and Correction, later called the National Conference of Social Work. The Memorial History of Loulsville, nerspaper accounts, and personal conferences with Board members and workers in the Institution have supplemented the informetion secured from the reports.

1 Henry W. Thurston, The Dependent Child (New York: Columbia University Press, I930, Introduction, p. $\mathbf{x}$. 
CHAPTER I

CHANGING AIMS AND METHODS

OF CARING FOR DEPENDENT CHILDREN 


\section{CHAPTER I}

CHANGING AIMS AND METHODS

OF CARING FOR DEPENDENT CHIIDREN

One of the most perplexing problems that society has had to face since the breaking up of foudalism has been that of caring for delinquent and dependent children. Until that time the lord of the manor was responsible for the welfare of 211 those who were under his domain; with the overthrow of the feudal system It became apparent that the charitable efforts of the church and the well-to-do were insufficient to carry the whole burden of caring for the poor. The Elizabethan Laws in England placed the responsibility on the community, out of public collected taxes, for caring for those children who were left neglected and dependent because of the inability of their parents or of private agencies to care for them.

Many efforts have been made by those interested in the welfare of children in America, to find the answer to the problem of the best type of care which society is able to give those unfortunate children who

${ }^{1}$ Ib1d., p. 6 . 
are dependent on tax-supported agencies for their wellbeing. Henry W. Thurston in his book The Dependent child has traced the efforts of society in America to find the answer to this problem. He describes the following stages in the changing aims and methods of caring for dependent children:

1. Indenture

2. The Mixed Almshouse

3. Orphan Asylums

4. Free Poster Home Caro

5. Individual study of the child's needs in terms of care

These methods have all been used in Louisville and Jefferson County with varying results.

\section{INDE NTURE}

One of the first methods to be tried in caring for these unfortunate children was by means of indenture, which was primarily an organized system of industrial apprenticeship. Indenture was a business deal which was supposed to benefit both the child and the adult to whom he was apprenticed. By this arrangement the dependent child was to receive food, clothing, shelter, and training in a craft or trade; at the end of the term of indenture he was to be given same money 
to begin a career of his own. In return for this the child was supposed to give the full equivalent in work. The veakness of this system lay in the fact that the treatment of the individual child was dependent almost entirely on the personality of the child and of his employer. The influence of the opinion of neighbors and a small amount of supervision of public officials was the only protection that a child had against abuse in this system.

The greatest evil in this system of caring for dependent children arose when boys and girls in large numbers were taken off of the streets in Eastern cities and shipped to farms in the mid-west, with little investigation of the foster homes to which they were being sent, and littie supervision of their treatment after beling recelved into the home. Reverend $E$. Wright, agent for the New York Juvenile Agylum, wrote regarding this practice that it would be an easy matter for them to place thousands of children annualig in homes in western states if that were all that was required, but he added, "Of all the outrages that have occurred in the name of Christian charity, none is more reprehensible than that of leaving helpless children

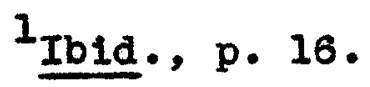


-1thout recourse in such situations."

While indenture was one of the means used to care for some of the children sent to the House of Refuge in Louisville, provision was made againgt such abuse as has just been described by a legal act which stated that no child committed to the House of Refuge should be apprenticed or employed by the Board of Managers out of the State of Kentucky.

It was the custom of the superintendent of the House of Refuge to make periodic visits to the farms where the boys were placed to ascertain the situation of the boys. The farmers to whom the boys were indentured were required to write a letter at stated intervals telling about the welfare of the boys; many of these letters are included in the annual reports to the mayor. The Superintendent often wrote accounts in his Journal of boys who had been indentured. In one entry

$1_{\text {Lyman P. Alden, The Shady Side of the Placing }}$ Out System: Proceedings of the conference of charitles and Corrections, 1885, p. 201. (Hereafter references to these conferences will be listed simply as Proceedings)

2 Acts, Ordinances and By-Laws Relating to the Loulsvilie Industrial school of Reform, I9I0. Act pessed March 3, 1860. Section 10.

${ }^{3}$ Iouisville Municipal Reports to the Mayor for the Fiscal Year Ending December 31, 1868. (Bradley \& GIbert Publishers) p. 19. (Hereafter the references to these municipal reports will be given simply as Municlpal Report). 
he wrote of a boy who had been indentured to a farmer in Oldham county. This boy had been allowed to come to Louisville to the Fair, but preferred to spend his time visiting at the House of Refuge. The boy seemed contented and happy in h1s new home, and spoke with pride of two and a half acres of fine peach-blow potatoes from which he expected to realize quite a little 1 sum of money. In his annual report for the year 1871, Superintendent Caldwell makes this statement:

In respect of the boys indentured since the openof the House, not a single complaint has reached us during the year, excepting one who returned of h1s own accord to the Refuge, and another who on account of 1ll-health, I recomended to be sent to the care of h1s friends in Illinols rather than allow his return to the House. 2

However, since most of the chlldren admitted to the House of Refuge were taken from the city streets, it is reasonable to suppose that all did not adjust to country life as well as the above quotation would lead one to think. Mr. C. H. Fetterolf, president of the alrard College for Orphan Boys at this time, wrote that his experience with farmers had not been satisfactory; they were not considerate of the child's welfare, caring only to use him for their profit.

${ }^{1}$ Superintendent's Journal from the Municipal Report 18ర\%, p. 45 .

2uniclpal Report, 1871; p. 22 .

${ }^{3}$ Alden, op. c1t., p. 202 . 
While the indenture system seemed on the surface to be a good solution for the problem of teaching dependent boys and girls a trade, experlence has shown that except under close supervision this system leads to exploitation and 1nadequate training. Likewise, it is no longer thought that the children of the poor should begin to work at an early age in order to learn selfreliance and habits of thrift. Too often when these chlldren have been placed under apprenticeship contracts they have become neglected children, overworked and denied education and recreation needed for healthy 1 growth. For reasons such as these, the indenture system is no longer practiced at the Louisville and Jefferson County Chilaren's Home.

\section{MIXED ALMSHOUSES}

Another method of caring for dependent and neglected children was that of placing them in mixed almshouses. Mr. J. V. N. Yates, Secretary of the State of New York in 1823-24, made a study of the conditions of the poor which lead to his recommending that every county should purchase not more than two bundred acres and build thereon one or more buildings to be called

I Grace Abbott,. The Child and the State (Chicago: Oniversity of Chicago Press, 1938) pp. 191,193. 
the poor house of the county. This was done in order to protect the poor from being farmed out to contractors who would get what they could out of them, and also as a means to provide some education and training for the children of paupers. This idea to ok hold rapidly throughout the country; the Loulsville Directory for 1832 describes the clty poor and work house, located at Chestnut street between Ninth and Tentb:

It accommodated the poor of the city as well as the slck, and is used to confine those to labor who do not pay the fines inflicted at the Mayor's court, at the rate of fifty cents a day until they discharge their penalties.

The annual report of the trustees of the Almshouse for the year 1857 gives a picture of life in the almshouse which the imagination can fill in to understand what it meant for the children confined therein. Of the two hundred and thirty-two persons admitted during the year, sixty-three were children. of this number nine adults and eleven children died while in the almshouse.

${ }^{1}$ J. V. N. Yates, The Relief and Settlement of the Poor--Extract from New York Leglslature. Report and Other Papers on Subject of Laws for Relief and Settlement of Poor (In Assembly Journal) January, 1824 pp. 386-99, AppendIx B; (Senate JournaI, Appendix A): reprinted in $34 \mathrm{th}$ Annual Report of the State Board of Charities of the State of New York, convenlentIy condensed in: Sophonisba P. Breckinridge, Public Welfa re Administration in the United States--Select Documents (2d ed.; ChIcago, UnIversity of Chicago Press, 1938) p. 40.

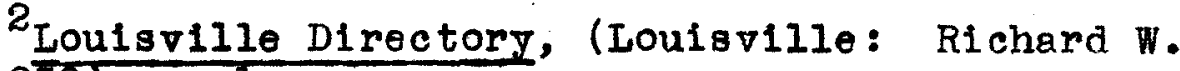
Otis, 1832), p. 1. 
Elght children were born to mothers who were confined in the institution. Six people diagnosed as baving syphilis and two with gonorrhea were housed w1.th these chlldren, aged people, alcoholics; to complete the picture there were three eplleptics and five idiots. There was no school provided for the children confined in the Almshouse in Louisvilie; the report says in this regard:

We have no school, and cansequently no teacher. As regards a teacher, there has been no necessity whatever for one until within the last few days, there not being a sufficient number of scholars to justify employing one. In fact, there was but one child in the almshouse capable of receiving instruction until within a very brief period; the rest of the chlldren being either too young, or mentally incapacitated to recel ve any information, from such a source. At the present time, there are several children as inmates, fully qualified, both in point of age and intelligence, to attend school, and this matter will not be neglected. We shall open a school on the first day of April, pursuing at the same time, the course we did in abolishing the pay officers, as before mentioned. I feel satisfled that there can always be procured, some one of the inmates, fully competent to discharge the duties of teacher, so far as may be required for almshouse purposes, and thereby saving a considerable expense to the institution, Which 1 s an item of some importance. 1

In 1885 there was agitation for the removal of children from the almshouse, the board polnting out that there were some forty or fifty boys confined

$I_{\text {Annual Report of the Trustees of the Almshouse }}$ of the city of Loulsilile for the Year ending March 10 , 1857. (Huil and Brothers Printers), p. 9 . 
there who should be committed to the House of Refuge where they could earn a living and learn some trade which would be useful to them. In 1886 the Board adopted the policy of refusing admission of children to the almshouse.

\section{ORPHAN ASYLUMS}

Although the building of almshouses seemed at the time to be a step formard in caring for dependent and neglected children, it soon became apparent that the conditions which existed there made it an unfit place in which to house a child. The practice of keeping ohildren in almshouses was described in the first Wite House Conference report as being "an unqual1fled evil which should be forbidden by law." As a result those people interested in child welfare began to think in terms of bullaing separate institutions for the care of such children. The first orphan's home was established in New Orleans in 1729 by the Ursuline Convent; the first municlpal orphan's asylum was built in

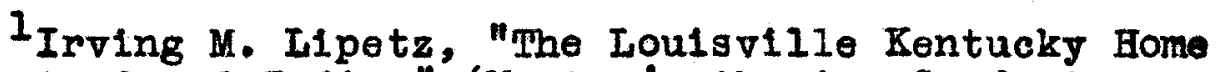
for the Aged and Inf Irm" (Master's thesis, Graduate Division of Social Administration, University of Louisvilie, 1942), p. 51 .

2 Proceedings of the conference on the care of Dependent ChIldren (Weshington, 1. C.: Government Printing of $1 \mathrm{ce}, 1909$, p. 11 . 
Charleston, South Carolina.

Credit is given to Mrs. Samuel cas sidy for being the mother of the first Orphan's Home Society in this vicinity. In 1834 she began an effort to found a Protestant Orphan's home; this later became the Eplscopal Orphan's Home, establishod October 6, 1835. St. Vincent's Orphanage was established in 1836, the Loulsville Orphan's Home Soclety in 1849, St. Thomas Orphanage 1850, the German Protestant Orphanage 1852, the Louisville Presbyterian Orphan's Home $1853 .^{3}$ Thus we see that many private orphan's homes were established In Louisville before 1854, nevertheless, they were not able to take care of all of the children who were neglected and dependent in this vicinity. Consequently a movement was begun to establish a public institution to care for boys who were showing delinquent tendencles. This $w 11$ be described in detall in the next chapter.

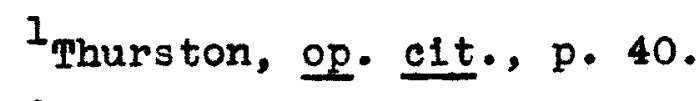

$2_{\text {Stoddard Johns on (ed.), The Memorlal History of }}$ Loulsville (Chicago: American Blographical Publishing Co., 1896) I, p. 186.

$3_{W}$. H. Slingerland, Child Welfare in Louisville, (Louisvilie: Welfare Loague publishers, April, 1919). 
FREE FOSTER HOME GARE

Although this was a period of rapid expansion in the building of institutions for the care of dependent children, there were st1ll those who felt that the proper environment for a child was in a private home. The free foster family home movement was begun by Charles Loring Brace, founder of the New York Children's Ald Soclety, in 1853. Mr. Brace rejected the form of indenture, but never the influence of its spirit. In form the service was to a needy child, but it was also made clear that he rould pay for all that was done for him in personality and work. The pert played by the child, the family, and soclety is summarized as follors:

1. The child is to get a real home which he is to pay for in work.

2. The family is to get a new interest in $11 f e$, and relief from the little cares of the farm.

3. The society is to bear the trouble and expense necessary to deliver the child and take him away again if a mistake has boen made and for any reason the child is not satisfactory. At the meeting of the conference of Charities and Correction held in 1885 there was much discussion as to

$1_{\text {Thurston, op. c1t., p. } 102 .}$ 
the relative value of the institution and foster home care. It was pointed out that the advocates of foster home care seemed to think that almost any home for a poor child was better than an institution. However, there were tro weaknesses in the thinking of those people, first in assuming that good homes could be readily found for every homeless child, and second that any family, however humble is the best place for every homeless child. Mrs. Virginia Ohr, for fifteon years the Superintendent of the Illinois Soldier's and Sallor's Orphan's Home, stated that their experience in placing children in homes had been very unsatisfactory. She hed found that the greater number of applications for children had no other aim in view than to secure cheap help.

With the development of the use of paid foster homes for caring for dependent chlldren, the use of the free foster homes is now rare in this institution. However, the reports of the Louisville and Jefferson County Children's Home show that this type of care is st11l in use to some extent. The present Superintendent says that some of these are adoptive homes where the child is kept without pay from six months to a year

${ }^{1}$ Alden, op. c1t., p. 201. 
pending adoption. Others are the homes of friends or relatives of the chlldren who were keeping them under the supervision of the Home, but without pay. St1ll others are homes where the foster parents had been paid for keepling the child, but were now keeping him without pay rather than have him returned to ormsby Village.

INDIVIDUAL STUDY OF THE CHID'S NEEDS IN TERMS OF CARE Mr. Charles W. Birtwell, Boston Chllaren's Ald Society, 1886, is given credit for invoking the ald of science to supplement the sympathy and sentiment that had been used in trying to find the solution for the problem of caring for delinquent and dependent children. It was in this society that the beginning of case records was made. The mistake previous to this time was not in fallure to see some of the needs of the child, but that of thinking that there was just one best way of meeting all these needs. Before making plans for a child it is necessary to understand not only his physical needs, but his emotional and intellectual satisfactions as well. In order to do this one must know how these needs have been met in the past, what has been

$I_{\text {The present Superintendent, Mr. H. V. Bastin, has }}$ supplied this information, August, 1943. 
the meaning to the child of his previous experiences with his father, his mother, his slblings, his eriends, the nelghborhood in which he has 11ved. Can one be sure that by taking him out of his familiar surroundIngs, however filthy, dopraved or immoral, and putting him in a clean, well-managed home one has helped the child in terms of his own inner needs?

The most impressive thing observed by the writer in making this study of the Loulsvilie and Jefferson County Children's Home was the manner in which each child is considered as an individuel from the time of his commitment until his dismissal. At the Children's Center careful psychological tests and case histories are made to determine what kind of care is most suitable for this particular child before placement is decided upon. Those children kept in their own homes or placed in foster homes are supervised by trained case workers, while those comnitted to the village are under the constant supervision of a well trained staff of norkers.

An excelient example of the individual attention given to the child's needs was observed by the writer when she attended a councli moeting at the

$1_{\text {Thurstion, op. c1t., p. } 200 .}$ 
Village in September of 1943. This council which meets once a week, is composed of the Superintendent, the psychiatrist, the head cottage mother, other cottage mothers whose children will appear on that day, the principal of the school, the child's teacher, the head of the social service department, the psychologist, the Catholic priest, the Protestant minister, the director of vocational training, and similar representatives from Ridgewood. ${ }^{1}$ Any child who feels that he has a problem that requires apecial consideration is given an opportunity to bring it before the council. The child comes at his own request, and not because he is surmoned to appear. A brief summary of the case is presented by the social workerbefore the child is admitted to the roam; the chlld is then brought before the group to present his case as he sees it. In an informal and kindly manner he is helped to analyze his own problem, the Superintendent and psychiatrist usually taking the lead in the conversation. When an understanding has been reached between the two, the child leaves the room while a vote is taken on the decision of the council. The child then returns to the

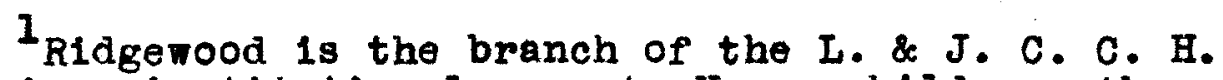
whlch gives institutional care to Negro chlldren; the campus is adjacent to Ormsby Village. 
group and is told of this decision; it sometimes happened that the child was disappointed in the outcome of the decision, but the writer had the feeling that he never left the roam without the confidence that the group was acting in his best interest.

Once or twice during the meting there was some besitation about making a decision because of the fear of establishing a precedent that would cause difficulty later. A Board member who was present remarked that individual cases were always more important than rules; that it was always better not to have too definite rules but what you could break them for the sake of the individual. That remark seomed to sumnarize the whole attitude of the workers at the Louisville and Jefferson County Children's Home: the individual needs of the individual child are always of paramount importance. 


\section{CBAPTER II}

CHA NGES DUE TO INCREASING NEFDS FOR SERVICE TO CHILDREN IN LOUISVILTE AND JEFEERSON COUNTY 
CHAPTER II

CHANGES DUE TO INCREASING NEEDS FOR SERVICE TO CHILDREN IN LOUISVILLE AND JEFHERSON COUNTY

\section{Conditions Leading to the Establishment of the House of Refuge In 1854}

Although, as proviously clted, a number of private orphan's homes existed in Loulsville by 1854 , there were many chlldren in Loulsville who needed protection which they did not have. I quote Miss Prances Rabon, who was placed in the House of Refuge In 1890. She sald that at the time the House of Refuge was founded river traffic was the principal means of transportation; Loulsville's position on the Ohio brought many drifters to the c1ty. Miss Rabon told of a gang of boys who l1ved on the water-front, known as "the forty thleves" who were the nucleus for the flrst group to be placed in the House of Refuge. Beside these delinquent children, at the close of the C1vil war, there were many widowed mothers who were not able to take care of their children, and sought assistance from the city in making plans for them. Miss Rabon stated that in the church homes the children were subject to adoption, so that many mothers preferred to place their children in the public home, hoping to be 
able to take care of them themselves at a later time.

The following editorial appeared in the Dally

Courier of January 18, 1854:

When is Loulsvilie to have her House of Refuge for Juvenile offenders? Very fow cities within our lmowledge stand more in need of such an estabIlshment. Among all the public institutions of Cincinnatti, she has not one which is more to her credit, then that which was erected a fer miles out of town through the exertions chiefly of the late James H. Perkins; nor has she one which is doing more for her future quiet.....

There is a noble institution which we should like our friends here to emulate, when they get ambitious of taking their place side-by-side with our up-river neighbor. Has not Loulsville a James H. Perkins who wili move in this matter?

Another editorlal appeared ten days later:

We doubt if there is a city in the United States in which the beneficial effects of House of Refuge and correction for juvenile delinquents would be more instantaneously and more generally felt than in Louls ille. The number of abandoned young girls in this city, is not so large we the nk as in most other citios of equal population; but the boys here have all the vices that belong to boys in the worst parts of the country. In drunkenness, in smoking and chowing, in thieving propensities, in the use of valgar and profane language, the boys of Loulavilie are about as great adepts as we have seen anywhere. And in reference to the girls it is apparent that a more evil day is coming--for when you see females ten to fourteen years old carrying peddling baskets, picking up rags in the streets, and begging from comer to comer, you behold most

${ }^{1}$ Personal interview with Miss Frances Rabon, nurse at the Children's Center, who has had continuous connection with the Home since 1890, June, 1943.

${ }^{2}$ Da11y Courier, Wednesday, January 18, 1854. 
probably in nine cases out of ten the beginning of an evil that will be most deplorable.

The editorial continued with a description of the philosophy which lay behind the House of Refuge movement. It said the first idea in these institutions is that of affording to those who are placed in its walls a refuge from the temptations to which they have been aubjected, the second is to give them mental training as well as training in domestic labor and mechanical art, the last Idea was that of administering corporal correction, which was found by experience to be rarely needed and st111 more rarely employed.

Apparently a James $S$. Perkins was found for Louisville, for on March the ninth less than two months after the editorials appeared, the institution was incorporated. The first board of managers of the inst1tution was composed of Messrs. Willlam F. Bullock, Henry Pirtle, John Joyes, Edward Garland, Wm. S. Bodley, Jas. S. Speed, M. Cody, Curran Pope, Wm. F. Pettit, Wm. E. Brooks, Wm. Garnet, Samuel Forwood, Wm. Kendrick, B. M. Patton, L. I. Iurton. Provision was made for a biennial election of fifteen members of the Board, elght to be chosen by the general 
councli of the elty of Loulsville, and seven by such Individuals as may have contributed to the establishment and maintenance of the House of Refuge fifty dollars at any time, or five dollars annually for twelve years, or five dollars for the year in which the election may take place. Thls law stated that any boy under elghteen and ang girl under sixteen, being a resident of the city of Louisville, might be taken in as beneficlaries. It gave the Bosrd the power to employ the children committed to their care in such a way as may be suitable to their years and capacities. It also gave the board the power to bind such children out as apprentices "to learn such proper trades ard employments, as in their judgment will be most conducive to the reformation.... of said children."

In $1851 \mathrm{Mr}$. Thomas Brown, a banker of Louisville, offered the city of Louisville eighty-two and a half acres of land lying between Brook and Third and $D$ and I streets for the sum of ten thousand dollars. Th1s land was offered to the clty for a park, but no steps were taken to convert it into a park by the of ty; Instead it was given by the city to the House of Refuge

${ }^{1}$ Laws of Kentucky, Acts of the General Assembly of the Commoniealth of Kentuaky (Frankfort, Ky.: A. G. Hodges State Printer, 1854) Chapter 801, p. 368 . 
In 1860. In 1859 sixty thousand dollars had been approprlated for a bullding; this bullding was completed just in time to be taken over for use as a war hospital. The Memorial History of Louisville states that it was reloased at an aupicious time, for through the operationof the contending amies "many little boys were thrown upon the world without resources, and without their natural parental protection." ${ }^{1}$

There now remained the problem of selecting the Superintendent of the institution. The wisdom of the Board is shown in their selecting a man for this position who had the qualifications that Mr. Peter H. Caldwell, the first Superintendent, possessed. Mr. Caldwell was a native of Huntington, Canada; he was reared on a farm, educated in New York and in Middlebury College, Vernont. For ten years he was a teacher in Chicago, and after that was auperintendent of the Reform School of Chleago for a year and a half. He was acting in this capacity when the committee went to talk with him about the position in Loulsville.

The committee was pleased with his personality

\section{IJohnson, op. cit., Vol. II, p. 339. \\ 2 Industrial School Gem (A publication of the} Loulsvilie Industrial School, November 16, 1907) p. 4. 
and qualifications, but were hesitant about employing him on only one score; they desired a married man for the position. Mr. Caldwell agreed to remedy that situation on short order. Two days before he ras to take charge of the institution he married Miss Hary Tommsend Wells, also of canada, who had been principal of the Chlcago School of Reform for several years. Their honeymoon was spent at the House of Reform.

The president's report for 1869 describes these two people thus: For a great proportion of the success that has attended the operations of the House of Refuge the past year, all honor is due to the able and indefatiguable Superintendent P. Caldwell Esq., and not less to his elegant, accomplished and zealous wife, who heartily assists in 811 these labors, as if they mere indeed works of love. We have never seen two persons more admirably qualified for the positions they occupy.

Since Mr. Caldwell was superintendent of the Institution for forty-eight years, much of the philosophy that went into its bullding is expressed in his reports, which will be quoted frequently. It is evident through-

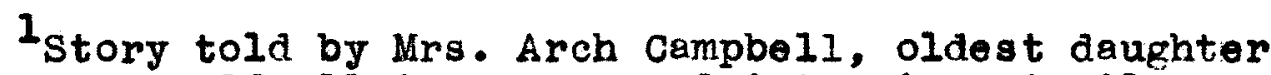
of Mr. Peter caldweli in a personal interview, April, 1943.

2Mayor's Report, 1869, p. 6 . 
out that he was an educator as weli as a reformer, that from the beginning the institution was considered as a school for training youth to take their place in society. After tracing its growth due to increasing demands, we shall examine the philosophy which has gone into the building of the Loulsvilie and Jefferson county Chlldren's Home.

Changes in the Institution to Meet Growing Needs Six years after the House of Refuge was opened to boys, the need for having similar care for girls made it imperative to add a building which would house white girls. Twenty-five thousand dollars was get aside to build a house for this purpose. In 1873 white girls were admitted to the institution. This was somewhat in advance of the general thinking of the times as shown in a report made at the National Conference of Charities and correction in which the statement was mede that the slight provision for reformation already made was for boys malniy. Fifteen of the reform inst1tutions were for boys only, four for girls only, and eleven for boys with only a small department for girls. In many cases of the latter type when more space was needed for boys, the girls were crowded out. The report was concluded with the statement that the reformation of 
vagrant girls was generally thought to be hopeless; they were left to the street at the mercy of unprincipled and vile men until they became too troublesome to be endured.

Whe President of the Board, commenting on the opening of the House of Refuge for Female Offenders said, "Although by many th1s branch of reform is looked upon as but labor in vain, we have great hopes for its ultimate success." In the Superintendent's report for the same year this statement is made, "The management of these refractory girls has been a far more dellcate and difficult task than the control of the boys." The following year the Superintendent remarked that the Female Department above all others claimed his attention and sympathy; he felt that the problem of what was to become of the young females when their terms expired wauld be a question more easily propounded than answered.

Three years later Mr. Caldwell seemed more opt1mistic over the propsects for this department, saying that the Female Department was meeting their highest

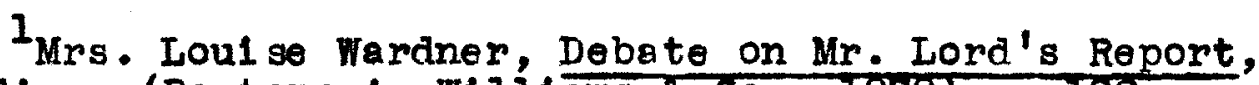
Procoedings (Boston: A. Wililiams \& CO., 1878) p. 189. 2Mun101pal Report, 1873, p. 27.

3 Ib1d., 1874, p. 224. 
expectations. He said that four of their girls had been married in the past year, and were seemingly happy and making good wives. A former inmate had spent a week of her honeymoon at the Home; he described her as being a model woman, even beautiful and accomplished, who was proud of her former home, and thankful to the kind providence which had afforded her such a happy means of escape from the miserable life which had been hers 1 previously.

However, Mr. Caldwell was not always so optimistic over his work with girls; in the following words ho described what he felt to be the typicel difference between boys and girls:

The girl is to-day fltful, freakish, whimsical, passionate, strong in her likes and dislikes, repentent and sorrowful; tomorrow she may be cold, sulky, and stolid, selfish, seoking only her own gratification and pleasure. A boy is less selfish, less splematic, more sober, generous and constant. A girl's disposition is more apt to be meteoric, coming and golng; the boy, sun-like, continuing the same. A girl's moral advancement might be compared to the motion of a feather in the air, gyrates much, flies seldom ever; but a boy's is eagle-like, which when it starts for the sun, will continue in its course, even though winds and storms and clouds should intervene. A girl wants constant encouragement, care, praise, frequent attention.

Four years after white girls were admitted, it was deemed necessary to erect a bullding to care for

$$
{ }^{I_{\text {Ib1d., }}} \text { 1877, p. } 535 .
$$


colored boys (1877); nineteen years later (1896) colored girls were admitted. Although both colored and white childien have been cared for in the same inst1tution since these dates, unfortunately, the advantages have not been the same for both races. Further comment will be made on these differences in the last chapter of this thesis.

In 1912 Jefferson County established a Parental Home for the care of the dependent white children in the county. This home was located at Ormsby Station. By an act of legislature in 1920 this home was combined with the Industrial School of Reform, but 1t was not unt1l February of 1925 that the inmates of the latter institution were moved to the Ormsby location. In March of 1927 the name of the school was changed to Ormsby Village. Ormsby Village is but a part of the Loulsville and Jefferson County Children's Home, however. In accordance with the change in thinking as to the best type of care for delinquent and dependent children, there has been an increasing tendency to place chlldren in foster homes, or wherever posstb le to keep them in their onn homes. The Foster Home Department was added in 1924, and Mother's Ald established in 1926. This was in keeping with the memorable statement made by President Theodore Roosevelt to 
Congress in 1909 in which he said, "Home life is the highest and finest product of clvilization. Children should not be deprived of 1t except for urgent and compeling reasons." 1 The earliest work of the fosterhome department had to do primarily with placing older girls in so-called wage or school homes; this was before there was an accredited High School at Ormsby Village. In 1930 the policy was established of placing infants and pre-school children in foster homes without first coming to the institution; later this was extended to children in the primery grades.

It is interesting to note in regard to those children who are beling cared for by Mother's Ald that there is a smaller inclience of juvenile delinquency among these children than among the entire population of the county. In 1933 Miss Martha Dav1s, who was in charge of this department, discovered that in the entire population of the county one out of forty children was brought to the Detention Home, while there were only one out of sixty-five of the Mother's Ald children

${ }^{1}$ Proceedings of the Conference on the care of Dependent ChIIdren, op. c1t., p. 5 .

Margarett Weber, Working with Dependent and Delinquent Children in the Same Institution, (Louisville, kentucky: Ormsby ViIIage Press, 1935) p. 4. 
1

brought to the Detention Home.

The Osborme Report findings showed that the extra-mural population of the Home was constantly increasing, while the ingtitution population remained stationary. In 1925 the institution population comprised two thirds of those under care, while in 1933 it represented only a fourth. In 1942 the institution population was four hundred and elght as compared to nine hundred and fifty-five children who were placed out.

Beslde the two institutions, Ormsby V1liage and R1dgewood, the Foster Home Department and the Mother's Ald Department, the Louisville and Jefferson County Children's Home also has charge of the Children's Center on Chestnut Street. In December of 1925 a movement was begun to abolish the Board of Children's Guardians which had the control of the Detention Home and to transfer the control of that institution to the Board of Managers of the Louisvilie and Jefferson County Children's Home. The object of this proposal was to unify the work $w 1$ th delinquent children, to

\footnotetext{
${ }^{1}$ Ib1d., p. 3 .

2 Handbook of American Institutions for Delinquent Juventles (Ist ed.; New York: Osborno Assoclation PubIIshers, 1940), II, 40. (Hereafter this w111 be referred to simply as the Osborne Report.)
} 
centralize the responsibility, to eliminate duplication, reduce expenses, and Improve the type of service to children. This transfer was completed in 1926. While the child is held in the Children's Center a psychological study is begun, and an effort is made to understand his ablitties and his problems, to discover his interests and wherever possible to relate them to the activities of the campus at Omsby Village or Ridgerood if he is to be sent to elther institution.

${ }^{I_{\text {Minutes }}}$ of a called meeting of the Board, December 24, 1925.

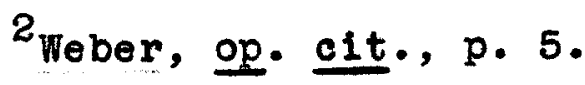


CHAPTER III

CHANGING CONCEPTS OF CHIID CARE IN REGARD TO TORK AND SEPARATION OF DELINQUENTS AND DEPENDENTS 
CHANGING CONCEPTS OF CHILD CARE IN REGARD TO WORK AND SEPARATION OF DELINQUENTS AND DEPENDENTS

\section{Changing Philosophy in Regard to Work}

There are certaln problems which are common to every institution which has the responsibility of caring for delinquent, dependent and neglected children. In the Superintendent's reports of the Iouisvilie and Jefferson County Children's Home many of these problems are touched upon again and again as the same man seos the problem in a new light, or his successor expresses a different idea about the best manner of handling the situation. In his first annual report to the Mayor, Mr. Caldwell stated what he considered to be the purpose of the Institution: he belleved that itg benefactors had not established it for a work house, though diligence was expected in the work assigned the boys. It was not founded for a juvenile penal institution, though punishment was sometimes necessary for the reclamation of the child. He felt that the great aim of its benefactors was to make the house a refuge in all the length, and breadth and helght of the meaning of the word. W1th this ideal in mind, the workers in the institution did not allow themselves to look upon 
the child committed to their care as "a bundle of falsehoods, dishonest, a doomed felon, or a law-sentenced vagabond, but as a being whom God had created with tastes, habits, weaknesses and temptations peculiar to himself." It was their task to help the child to govern and control these weaknesses so that they would "redound to the good of the child and the glory of the creator." Mr. Caldwell, who was of Scotch ancestry, had the greatest faith in work as being one of the best cures for the kind of vicious habits that delinquent boys are prone to form. In his second annual report he stressed that feature of his success, saying that there had been great improvement in the work department during the year, though he still did not feel it had reached the proper standard. He felt the need for having a greater variety of work, and also provision for work on a surer basis. He expressed the opinion that work was not the chlef agent to be used in reforming a boy, but he was quite certain that it had a great deal to do with 1t. In order to drive out wicked thoughts from the mind, he thought it was necessary to put other thoughts in their place, and the way to do that was to give him something to think about. Hablts

${ }^{1}$ Mun1e1 pal Reports, 1866, p. 23. 
of industry, which to him were basic to reform, were to be achleved only through the experience of working. Mr. Caldwell considered industry, if not the parent of reform, a very close relative.

The chlef problem as Mr. Caldwell saw it, was not to carry on the House of Refuge as a business matter so that profitable work was accomplished, but so to conduct the affairs that when the boys left the home where a watchful eye had been kept on them, they would have achleved the proper attitude toward work that they would do their part in soclety under any and all clrcumstances. He had observed that boys and girls who had been taught to work at home were seldom brought to the home on account of misbehavior. For that reason those who came needed to be taught to work, not for the support of the institution but for their own good. Consequently the effort was made to secure the kind of work that would provide many with occupations, rather than the kind that would bring large earnings in proportion to the amount of work done. The benefit to the institution of the money secured by the rork of the boys was always to be considered as secondary to the inculcation of industry in the lives of the boys.

I'Ibid., 1871, p. 20. 
Mr. Caldwell thought a further benefit of having work done by the boys and girls in the institution was to keep it on a realistic basia. He expressed himself as not being the kind of person who thought everything should be so lovely and sweet in a public institution that children would go through the street crying for admittance to that beautiful spot. He told of being stopped frequentiy on the street by boys who asked him, "Will you make me work if I come out there?" His reply was "Certainly." The boy then inquired, "Well, suppose I do not want to work?" Mr. Caldwell informed him, "Then you won't eat; your stomach will put your hands to work if nothing else will." "Well, you won't catch me out there then" was the usual response.

The problem of work in juvenile institutions was one that was under discussion at the Conference of Charities and correction soon after this time. The following flve points were listed as being important to consider in planning work in a juvenile reformatory:

1. The teaching of trades should be carried on solely for the benefit of the pupils, and without a thought of the financial profit to the institution.

$$
\begin{aligned}
& 1_{\text {Ib1d., } 1877, \text { p. } 533 .} \\
& 2_{\text {Ib1d., } 1880, \text { p. } 167 .}
\end{aligned}
$$


2. Those trades should be taught which give opportunity for employment to large numbers.

3. Care should be taken in assigning boys to trades in which they show an aptitude and interest.

4. It is of primary importance to select properly qualified teachers for the se trades.

5. It is in the interest of economy to provide good tools with which to work in a trade $\mathrm{school.}$ The thought was expressed that too much attention had been given to caring for the immediate needs of the inmates of these schools, and too little to preparing them for successfully grappling with the problems of Ilfe as they would find them upon being dismissed from the school. Consideration needed to be given to the ages of the pupils, the majority of whom were between twelve and elghteen years, their previaus training, and the probable time of their remaining in the institution, usually not longer than two years. The problem was summarized into this question: What trades are appropriate to teach boys between twelve and elghteen years old, who have had limited educational advantages, who are to remain in the school about two years, which will enable them to be self-supporting upon dismissal,

${ }^{1}$ Lev1 S. Fulton, The Technologic System, Proceodings, 1888 (Boston: GeO.H. EIIIs printer) p. 215. 
and which. Will be desirable for them to follow as a Iife profession? 1

A reflection of this same thinking is seen in the Superintendent's report a few years later when he recommends that the purpose of the work in the institution must be not to flgure on how much the children's labor can earn, but to give the child the greatest possible advantage to acquire earning ability for his own future. He recommended that the children be absolute charges and burdens during their stay at the school if need be, in order that they be able to become valuable elements of social wealth and usefulness in the years after their dismissal. Statistics are quoted showing that in this country les than twenty per cent of the convicts have any training in skilled labor, and seventy-five per cent are illiterate. The conclusion is drawn that every boy who has his own way to make is in danger of the penitentary until he has been taught some skilled trade and received some education in morals and 2 letters.

Mr. W. C. Brown, who succeeded Mr. Caldwell as Superintendent of the institution, saw the industrial

${ }^{1}$. A. Gower, Industrial Training in Juvenile Reformatories, Proceedings, 1888 (Boston: Geo. H. EIlis printer) p. 230 .

2 Municipal Report, 1892, p. 389. 
phase of the training given in the school as the princ1pal means of reclaiming the boys and girls who were committed to the school. His attitude might be summarlzed in the following statement made to the Board:

With little fear of successful contradition, I belleve it can be stated that regular and wholesome work is the true basis for permanent reform and the value of all institutions must, in large measure, be determined by the indugtrial effic1ency of the product they grind out. 1

With a change of personnel within the Board in 1920 there began to be alfference of opintion in regard to the importance of industrlal training within the institution. The new Board members felt that a broader educational program was needed than the limlted industrial training that was given; Mr. Brown did not share these views with the Board. At length it became apparent that the superintendent and the Board could not work in hamony, so a called meeting of the Board was beld october 24, 1923, to discuss securing a new Superintendent. In selecting the new man for this position, the Board turned to a person whose primary interest was education--Mr. George Colvin, who was serving as Superintendent of Public Instruction at Frankfort. Mr. Colvin served only three jears as Superintendent of the Home, after which time he became the President of the

$$
{ }^{1} \text { Municipal Report, } 1915, \text { p. } 432 \text {. }
$$


UnIversity of Loulsoille.

After this period there is seen a declded change in emphasis from stressing the value of work to the importance of education in the broader sense. Mr. Colvin never mentioned work in his reports but was interested in the amount of time that the children had for play. A study was made to determine how much time the individual child was free for play, or any desired use of leisure time. It was discovered that only one boy in the institution had less than two hours of play during each day; that was a half-witted nineteen year old boy who slept most of the time when he was supposed to be working, who "probably enjoyed more leisure than any other gentleman on the grounds." Mr. Colvin felt that the most notable improvement in that department was the fact that all of the children were leaming to play spontaneousiy and voluntarily; to him that was the best evidence he had seen that the chlldren were becoming thoroughly normal. 1

With the coming of Mr. Bastin as Superintendent to the institution, the same interest in education in its broeder sense is seen. The psychologist's report

\section{${ }^{1}$ Superintendent's Report (Unpublished) October,} 1925. (FFom this time on the publishing of annual municipal reports to the Mayor was discontinued. The material obtained was from the monthly reports to the Board which will be referred to hereafter as simply Report.) 
In 1930 states that in order to appreclate the excellent quality of teaching in the graded school it was necessary to understand sorne of the special needs that many of the chlldren showed; the new children in great numbers were slck children as far as school diagnosis was concerned. They were treated as such and given a thorough examination and study with treatment under specialists where that was needed. The school conceived its function to be to supply not only the same sort of grade organization as was sultable to normal children, but to give, special service where chlldren were in special need. Mr. Bastin made a thorough study of the sohool situation, arranged conferences with the state department of education and the department of education of the University of Kentucky and came to the conclusion that there should be offered at Ormsby village three separate courses of study--academlc, rocational, and 1ndustrial. The academic courses to be on such a basis that the students could transfer readily to the city schools, the vocational courses to include less academic matter and more farming and workshop, the Industrial course would include a minimum amount of academic work which would be fitted to those children who have low

\footnotetext{
$8,1930$.

${ }^{1}$ Psychologist's Report, (Unpublished), February
} 
I. Q.'s and who would not be able to f1t into the for enabling those high school graduates who seemed to be college material to continue their education in college or other specialized training.

Thus we see with the passing of the years in regard to the type of training given in the institution, the emphasis placed on adapting the training to meet the individual need of the individual child.

\section{Segregation of Dependent and Delinquent Children}

From 1ts founding, it was the policy of the House of Refuge to admit both delinquent and dependent children. In his second annual report the Superintendent, Mr. Caldwell, made a plea that those children who were guilty of no violation of the law, whose "morals were pure and untarnished from sin as our natures w11l permit" be separated from those chlldren who had already "added crime to crime and wickedness to wickedness." He recommended also that a third department be added where a boy could be placed on probation before being dismissed. He thought that the boy's reformation should be thoroughly tested by throwing

$$
1_{\text {Report, }} \text { April, } 1932 .
$$


temptation peculiar to life before him before he should be returned to society. He felt that a character that had been formed in the absence of all temptation was in no way fitted for getting along in the world.

Apparently the Board did not agree with Mr. Caldwell about the need to separate delinquent and dependent children, for twenty-five years later we find a similar plea. He stated that the innocent child, or the child of the virtuous poor should not be placed by law in daily as sociation with those children whose parents were living like beasts, and who since birth had been exposed to all the vices known to man. He thought it would be better to leave those chlldren to take their chances in the street than that they be compelled to live with those children who were dead to all virtue. Since the really viclous and incorrigible were not in the majority, Mr. Caldwell thought that much more could be accomplished if they were placed for one or two jears in separate houses until they could be improved nough in mind and morals to permit them to mingle with the other children.

At the time that plang were being made to unite

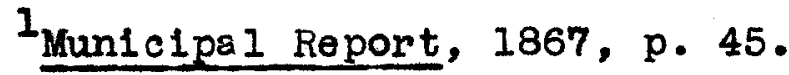

$2_{\text {Ib1d., } 1892, \text { p. } 389 .}$ 
the Industrial School of Reform and the Parental Home 1t was the thinking of the Board that 1t would be desirable to have the dependent and delinquent divisions of the Home as widely separated as possible, and that the two divisions should be apprasched from different roads. However, before proceeding with this plan a study was made of Individual cases to determine whether or not it was possible to classify children as delinquent or dependent at the time that they were committed to the institution. It was discovered that many of the children who had boen classed as delinquent had made a good adjustment within the institution, and had become good cltizens. On the other hand, chlldren who had been comitted as dependent or neglected often showed serious personality problems which would call for special treatment. As a consequence of this study, it was declded that all children should be admitted on the same basis, and given an opportunity to show themselves capable of self-control and self-discipline before being adjudged otherwise. Mr. Colvin considered this the most significant thing that had happened in the history of the institution for it marked the final transformation of a

$1_{\text {Minutes of the Board, July 1I, } 1921 .}$ 
correctional penal institution into a children's home. Until the time that the Parental Home and the Industrial School of Reform were united the treatment of the chllaren in the two homes was not the same; the question then had to be faced by the Board, should all the children be treated as delinquents or should they be treated as dependents? Or should separate quarters be provided for the two groups, with different treatment and different standards for each? When the Board refused to classify the children into two groups, and determined to consider each child as an individual, it built a home whose cornerstone was the possiblities of the child, and not its past performances for which it was not justiy responsible.

So strong wes the conviction of the Board that this was the best policy to follon that they were loathe to make any changes even when it was pointed out to them that it would be an advantage in some cases to try a different policy. After trying this policy for several years, Mr. Bastin came to the conclusion that separate quarters should be provided on admission for all delinquent chlldren where they would remain unt1l such time as it was no longer necessary for them to

${ }^{1}$ Report, 1925. 
be segregated from nomnal children. This applied not only to delinquent children, but also to dependent and neglected children who showed themselves in need of special disciplinary measures. He recommended that at least one unit in both the boy's and girl's departments should be provlded with locking-in faclities so that those children who were disposed to run away should be restrained from doing so.

Mr. Bastin felt that one of the most serlous personality problems with which they had to deal in a child was that of running away whenever a situation became unpleasant; he felt that in time it would lead to a complete breakdown of character and self-control. He said, "It is from the ranks of such persons that the fraternity of tramps, hoboes, and drifters constantly gathers its recrults."

Because Ormsby Village is bullt on the open system without any confining walls, the problem is more acute than in an institution bullt on the enclosed system. During the summer of $1932 \mathrm{Mr}$. Bastin made a special study of the causes of children going A.W.O.L., and found that they fell into four groups. The first group was composed of those children who got homesick

${ }^{1}$ Report, 1930. 
when they first came to the Viliage, and were not adjusted to the routine and orderly life there. Before they were able to adjust to this decided change in their 11ving, they ran away. A second group was composed of those children who had become worried about the family situation in their homes, and ran aray in the vain hope that they would be able to do something to remedy the situation. A third group was composed of those children who had got into same trouble on the campus and ran away rather than face the consequences of their actions. The fourth group was composed of those boys and girls who were of such low mental or emotional level that they were not able to hold themselves long in any gi ven course.

After making a careful study of the whole problem for six years, Mr. Bastin came to the conclusion that there was nothing that undermined stability of character so much as the hablt of running away from responsibilities and obligations. Some children ran away once or twice and then became adjusted to the regulations and developed enough character that they were able to resist the temptation, while others ran away continuously and repeatediy often inducing others to go with them. These latter became foct of infection in spreading the wrong attitudes among the other 
children. For this reason Mr. Bastin felt that the most urgent need of the institution was the erection of two treatment cottages where such children could be detalned until they had developed habits of self-control enough to warrant their becoming a part of the life of the village.

Mr. Bastin recommended that all the boys and girls be Given an opportunity to adjust on the campus when first committed to Ormsby Village, that only those be transferred to the treatment cottages whose conduct was detrimental to the welfare of the rest of the group. He thought that when a decision had been made, after a conference of workers who were interested in the child, the child should remain in the cottage for a period of not less than forty days. The children in these cottages were to be completely 1solated as to cooking, eating, sleeping, working, school work and recreation. The causes for which a child should be placed in the troatrent cottage would include:

A. Going A.W.O.L.

B. Clandestine meetings between boys and girls

C. Theft

D. Possessing stolen goods

${ }^{1}$ Report, June 1932. 
E. Serious misconduct such as drinking, smoking muggles, improper behavior with the opposite sex

F. Gross and continued disobedience

G. Refusing to work ${ }^{2}$

After attending the National Conference of Juvenile Agencies in 1941, Mr. Bastin reported to the Board that he hed discussed the matter of detention cottages with many superintendents, board members and comnissioners, and had found not one who did not agree that for a considerable part of the population in any Institution there needed to be a maximum security. Most states are giving maximum security to a majority if not all of their inmates; relatively few were attempting to classify them on their ability to adjust. In New Jersey and Californis those who can adjust are placed in one institution, with provision for a prompt transfer to a security institution for those who do not or can not adjust to an open one. Mr. Bastin felt that the ideal solution in this community would be for the state to offer a real tralning program at Greendale, with a provision whereby transfers could be easily effected between Orms by V1llage and Greendale. Pending a ch a solution, Mr. Bastin felt the

${ }^{1}$ Report, April, 1937. 
urgent need for making other provision in the inmediate future for those children who continued to present serious problems of conduct. He added:

I confess that I am somewhat desperate about the situation and feel, in spite of the recommendations thet have heretorore been made by such organizations as the Child Welfare League of America, the Osborne Association and others, that the plan of segregation be worth a serious trial.

He described the purpose of such segregation to be the giving of an intensive, individualized, constructive program to the delinquent group while in segregation. This program would require them to be constantly busy doing things within the range of their mental and physical capacities, things that would have some correlation with the experiences which they would meet in Ilfe, and things in which they would find pleasure and satisfaction. He felt that with such a program the memorles of doing unconventional and unlawful acts would tend to fade out, and as they found happiness in dolng the conventionel things they would become stablilized.

Aslde from the benefit to those boys and girls who could have specialized treatment by being kept in confinement unt1l they became stabilized, there rould

\footnotetext{
${ }^{1}$ Report, September, 1941.

2 Report, December, 1940.
} 
also be a benefit to the rest of the school by having them removed from the group. Mr. Bastin said there was growing and serlous disapproval among the children on the campus of those of the group who committed serious offenses such as going A.W.O.L., sterling and the like. The children expressed the following views of what heppened when these offenses were committed:

1. The whole school mas injured in the ejes of the public whenever a child ran away, stole, or committed an offense.

2. The public is likely to fudge the whole school by the record of the ones whose conduct is poorest.

3. The child who has a good record does not have as good a chance when applying for a position, because the public thinks of it as a place for bad chlldren.

4. The chronically bad child often persuades another child to participate with him in his misdemeanor, thus starting him out on the road to delinquency.

5. Ineffective methods of dealing w1th the bad child tend to confirm. him in his misconduct; he feels that the thrilis that he gets out of his exploits are worth while. To continue to 
keep him at Ormsby Village 18 an infustice to him as well as to the child who conducts himself 1

properly•

Within the past year the Board finally reached the decision to get aside two cottages as treatment cottages for boys and girls who were incapable of exerting enough self-control to benefit by the opportunities offered on a campus built on the open system. While in one sense this seems to indicate a change in thinking of the Board regarding the separation of delinquent and dependent children, it in no way means that children at Ormsby Village are arbitrarily classifled into delinquent and dependent children. All are admitted on the same basis and given an opportunity to make good in the new environment. Miss Feber who made a study of this situstion in 1935 said that where some occasion arose where information was needed as to whether a child had been committed as delinquent or dependent it was necessary to consult the records, for in many instances no one otherwise was certain whether the child was technically dependent or delinquent. The children are thought of as primarily neglected children who are in need of help, and an effort is made to give

${ }^{1}$ Report, January, 1942 . 
each child the kind of help from which he can gain the most benefit. 1

However, there is always the problem of a small group of boys and girls who are not capable of assuming the degree of responsiblilty placed on them by the freedom of the open system. The lock-up cottages are intended to give those boys and girls securlty and the opportunity for special treatment until they have galned enough self-control to be able to become citizens of such a community as ormsby viliage.

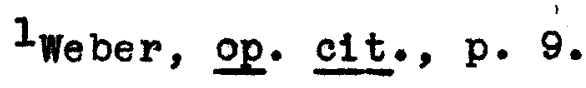


CHAP MER IV

CHANGING PHILOSOPHY IN REGARD TO

DISCIPLINE AND REIATIONSHIP WI TH PARENTS 


\section{CHAPTER IV}

CHANGING PHILOSOPHY IN REGARD TO

DISCIPLINE AND RELATIONSHIP WITH PARENTS

\section{Changing Philosophy in Regard to Discipline}

The conception of the proper function of an institution which cares for delinquent children has undergone a significant change in the pat century. This change has been reflected in the changing names of the institutions founded for this purpose. The classical school of penology founded by Beccaria in the seventeenth century held the viem that the criminal committed his offense in order to secure a posstble advantage. In onder to stamp out crime, the only thing necessary was to attach punlshments that were severe enough to outweigh the advantages gained by the criminal act. This thinking gave way to a more humane view In the nineteenth century when it was thought that the way to eradicate crime among young offenders was to provide them with a means to escape from temptation. As a result the first "House of Refuge" was founded in

$I_{\text {George B. Mangold, Problems of Child Welfare }}$ (Rev. ed.; New York: Macmillan Co., I924), p. 454.

2 paul H. Purfey, Social Problems of Childhood (Now York: Macmillan Co., 1929) p. 87. 
Now York in 1825. As the name implies, this was supposed to be a haven for delinquent youth where they would be protected from their own evil impulses by being removed from soclety. This movement gained popular approval throughout the nation; the name chosen for the institution established for this purpose in Louts ville in 1854 was the Loulsvilie House of Refuge.

The second change in thinkling regarding the best method of dealing with delinquent youth was the establishing of Reform Schools, where the alm of the institution was the complete subjection of the boy; repression instead of development was the keynote of discipline. In keeping with the trends of the times the name of the House of Refuge was chenged in Louisville in 1886 to that of the Industrial school of Reform. Thls was at the request of the superintendent, Mr. Peter Caldwell, who recommended changing the name to "one more consonant 1 th the character of the institution, and one which would grate less harshly upon the sensibilities of the children."

The third stage which saw the real hope of reform of delinquent boys to Ile in the teaching of a

$$
\begin{aligned}
& 1_{\text {Mangold, op. c1t., p. } 454 .} \\
& 2_{\text {Munlelpal Report, }} 1885, \text { p. } 317 \text {. }
\end{aligned}
$$


trade, was reflected in Loulsville by the change of name to the Louisville Industrial School. The experience of people working with delinquent boys showed that truancy and dissatisfaction with the school system were prominent factors in the problems of boys, so it was thought that if the emphasis in education could be placed on industrial training rather than literary, great improvement would be seen in the attitudes of the boys and girls.

The next step forward in the institutional care of children was the effort to realize in the institution the advantages of a home. Again this thinking was reflected in Louisville in the changing name of the institution. When the Loulsville Industrial School was combined with the Parental Home, and the move was made to Ormsby Station the name was changed to the Louisville and Jefferson County Children's Home. This change went far deeper than that of merely giving a new name to the institution, however, for it was then that the decision was made not to separate delinquent and dependent childicen, to abandon the enclosed system in favor of the open, and to erect the new bulldings on the cottage plan rather than the congregate. These 
extemal modifications were but symbols of the change in attitude toward the purpose and function of the institution. Nowhere is this attitude reflected more clearly than in relation to discipline within the institution. In talking with two members of the staff of the Louisville and Jefferson County Children's Home regarding the disclpline there, each felt that the changes had followed the thinking of the times in regard to discipline. Miss Rabon, who was placed in the House of Refuge as a ward in 1890 , and has continued to live in the institution as a worker ever since, gave an interesting description of the changes in disclpline as she has seen them. She recalled that the disclpline in her chlldhood was strict, but kindly. She said it was the habit of the little girls to watch for Mr. Caldwell to pass their dormitory, for sometimes he had pleces of candy in his pocket which he gave to them. They always looked to see how his hat was set on his head in order to ascertain whether it was an opportune time to run to $\mathrm{hlm}$, or whether it was better to avold bim then. If his hat were pushed back, they knew he would be in a good humor, but if it were pulled forward 1t was a sign that he had something important on his mind and they had better let him alone. Miss Rabon added that those who benefited from their stay in the 
House of Refuge praised the type of training there, while those who did not do well felt that it was the fault of the institution. She was glad that the discipline had been rigid during her stay there. She described the disclpline of the present as being much more lenient than that of her chlldhood, adding that the same is true in families of the present time as compared with those of her chlldhood.

The psychiatrist employed by the institution also stated that there had been a tendency in America in the past century to swing from one extreme to another in regard to its attitude toward the best method of discipline which would develop self-control in individuals. The latter part of the nineteenth century was a period when it was considered necessary to be very strict in matters of discipline. A stern, unbending attitude on the part of parents toward their children was considered the best one to adopt. In the nineteentwenties there was a swing in the opposite direction, to the laissez-faire attitude where a parent was so afrald of suppressing a child that he neglected to control him in any way. There is now a swing back in the other direction, a recognition that some restraint is necessary for the best development of the individual,

IInterview with Miss Frances Rabon, Nurse in the Children's Center, April, 1943. 
but that restraint is to be used only for the definite purpose of helping the person to grow into greater 1 self-control.

A reflection of this change in thinking is seen in the records of the superintendents of the institution. Mr. Caldwell had a great deal to say in his reports in regard to disclpline as such; he called it the "right arm of every reformatory system." However, he felt that all discipline should be administered th unwearing patience and tenderness. Any punishment that was vindictive, 111-tempered and violent, he felt to be ineffectual; the purpose of disclpline was to counsel, encourage, protect and control. Again and again Mr. Caldwell reminded the Board of the need for patience in trying to produce changes in character; he spoke of character as a growth that required time, the length of time that would be needed to produce the change would vary with each individual case.

Although Mr. Caldwell had strong convictions regarding the need for strict discipline in an 1nstitution whose purpose was to reform recalcitrant youth,

${ }^{1}$ Personal interview with Dr. Carl Whitaker, M.D., psychiatrist for the Loulsville and Jefferson County ChIldren's Home, June, 1943.

2 Mun101pa I Reports, 1887, p. 534, 545. 
he did not belleve in physical punishment. He stated that it only tended to disgrace and degrade the child and was of doubtful efficacy, to be resorted to only In exceptional cases. On the occasion of the twentyfifth anniversary of his coming to the institution as its superintendent, Mr. Caldwell delivered a public address in the chapel in which he spoke of his ldeas of discipline. The significant thing in that addresa was that he had no set of rules which he followed in regard to disclpline, but that each misdemeanor was an individual case which should be treated as such. He expressed his view on the need for individual treatment of each child in these words:

Here is a child and there is a rule. Now these two fixed quantitieg will not always unite in the same way. The same pattern will not fit every child's body, neither will the same method of administering truth or correcting evil do for every soul.?

When $\mathrm{Mr}$. Caldwell had been superintendent of the institution for a third of a century, he added an appendix to his report to summarize some of the changes in his philosophy during that time. He commented that his discipline had grown increasingly mild durlng those years, and that he had come more and more to consider

$$
\begin{aligned}
& 1_{\text {Ib1d., }} 1903, \text { p. } 192 . \\
& 2_{\text {Ib1d., } 1890, \text { p. } 533 .}
\end{aligned}
$$


the use of intelligence and affection as the best means of controlling children. He felt that punishment, however mild, should be used only when everything else had failed. His successor, Mr. Brown, who became superintendent in 1913, described his use of discipline as being kind but firmly enforced, carefuliy and judidiously employed. He felt that by this method he could engender the proper respect for authority. He stated that by administering discipline in the spirit of tactful and jucicious parents an attitude was engendered that disabused the mind of the child that he had the right to destroy his future if ho chose. He, too, was of the opinion that many people were inclined to expect the greatest amount of perfection from children who had shown the greatest evidences of imperfection. This was the occasion of much faultfinding and the supposed need for severe disciplinary measures. Mr. Brown felt that it should cali for a tempering of judgment and less severe measures.

In the short time that Mr. Colvin was superintendent nothing was found in the records regarding his Ideas of discipline as such. The whole tone of his reports shows that he did not consider the primary

$$
\begin{aligned}
& 1_{\text {Ib1d. , 1903, p. } 209 .} \\
& 2^{2_{\text {Ib1d. }}, 1913, \text { p. } 575 .}
\end{aligned}
$$


purpose of the institution to be punitive, which in itself is signifleant.

One of the first changes undertaken by Mr. Bastin when he became superintendent of the Loulsville and Jefferson County Chlldren's Home in 1926 was that of trying to aboligh corporal punishment in the institution. He expressed the opinion that where the indiscriminate use of corporal punishment was permitted, force, brutality, and hate became the dominant note of the institution. He felt that the effect of corporal punishment upon children was that of giving them a distorted view of life, of harboring resentments and injuries rather than bullding character. Consequently, he declded to try an experiment of inflicting no corporal punishment for a month. No one knew of this experiment except the assistant superintendent and the supervisor of girls. The experiment met with success in all cases except those of runaways. When 1t became generally known to the children that those who had run away were no longer whipped upon their return to the institution, the broke out a perfect epldemic of boys and girls golng A.W.O.I. CongequentIy, a public announcement was made that the

\footnotetext{
$I_{\text {Reports, }}$ 1923-1926.

$2_{\text {Report, January, } 1927 .}$
} 
experiment had been tried, but that it had not worked in the case of runaways. Therefore, in the future, until other means could be found to prevent running away, a whipping would be administered to any child going A.W.O.I. upon his return to the institution.

It was noted upon further reading of the minutes that after a short time it seemed necessary to resort to corporal punishment for a great many other offenses than that of running away. In November of the same year a chart is included in the Superintendent's report showing the number of whippings that month to be a hundred and elght. The reasons given for having to whip a child included that of going A.W.O.I., destruction of property, disobedience, disorderly conduct, fighting, impudence, lying, profane language, ralding frults and vegetables, stealing, the use of tobacco, neglecting work, and miscellaneous reasons. Each month for a period of years a similar chart appeared in the report. Howover, in a personal interview with Mr. Bastin, the writer leamed that the use of corporal punishment 1 a now extremely rare at Ormsby v1liage.

\footnotetext{
${ }^{1}$ Report, January, 1927.

Ibld., November, 1927.

3 personal interview with Mr. Henley V. Bastin, Superintendent of the Louisville and Jefferson County
} Ch1ldren's Home, June, 1943. 
With the coming of Mr. Bastin as Superintendent of the Loulsville and Jefferson County Children's Home, the records showed little mention of the negative side of discipline, namely punishment. Positive efforts to secure self-discipline among the boys and girls became the dominant note. One of the first efforts in this line was the establishing of allowances for the boys and girls, which as far as is known, was a unique experiment in an institution of this kind. Each boy and g1rl over twelve years of age was to recelve an allowance on the following basis:

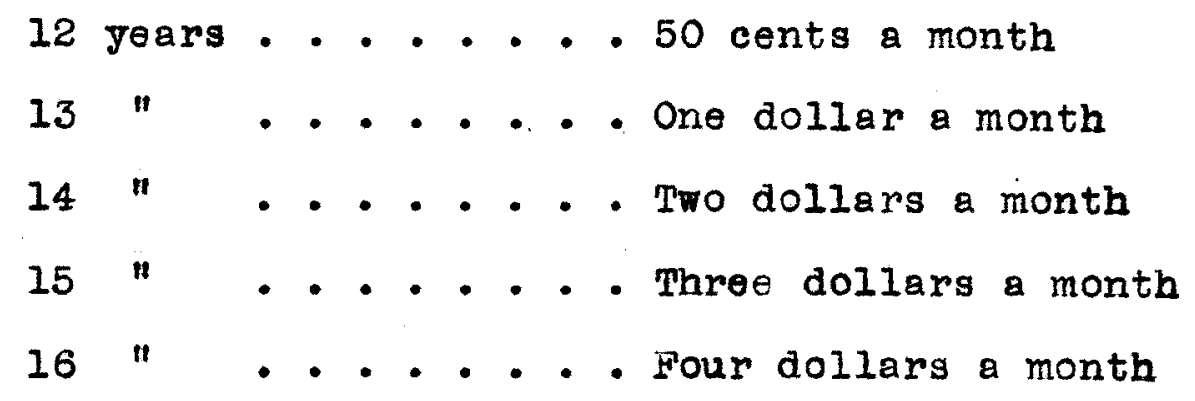

Since such a plan had never boen tried in an institution of this sort before, there was a great deal of misgiving on the part of many of the workers and Board members as to 1ts practicability. It was thought that 11 the children were permitted to carry money the disclpline problem would be greatly increased, that gambling and theft would result. Such did not prove to be the case, however. Not a single child falled to start a savings account, and although all were permitted 
to carry their surplus in their pockets and to spend it as they saw fit, the problems that were anticipated did not develop to any great degree.

Mr. Bastin described his purpose in establishing such a system in the following way:

One of the greatest dangers comes to the child when he earns his first money. The child who is unaccustomed to earning and using money, if suddenly paroled or placed in a position to earn a considerable amount, 111 probably find it impossible to properly adjust himself to the new situation. I an convinced that children should have some reasonable, uniform and positive way to earn at least a smali amaunt of money while at the institution. The 8 should be taught a proper 1 responsibility in the use of the money earned.

When he flrst brought up the subject of allowances for the children, Mr. Bastin sald that he felt the first responsibility of ang institution such as Ormsby Village was to train the children for the duties of citizenship. The more nearly the life in the institution could approach the life in an ideal home, the more nearly will its problems be successfully solved. He thought there would be a three-fold benef1t from introducling the allowance system:

1. It would teach the children to earn and use money.

2. It would be a reward for duties well performed.

3. It would be an effective disciplinary measure.2

${ }^{1}$ Report, October, 1926.

$2_{\text {Ibld., July, } 1926 .}$ 
The system has been in practice for many years now, and has proved to be as effective as the superintendent hoped for when it was established. There have been slight varlations in the system, such as changing the amount paid during times of financial pressure, but essentialiy the plan has remained the same.

A second positive appoach to the problem of alscipline was inaugurated by Mr. Bastin the following year. Mr. Bastin's attitude toward discipline was that any system that wes repregsive in character developed negative traits in the child which did more harm than good. He felt that an appeal had to be made to the intelligence and falr-mindedness of a person in order to secure his cooperation. As a step in that direction all of the children in the institution ten years of age or above were organized into four grades: Discipline, Admission, Apprentice and citizen. When child was admitted as a delinquent he was placed in the discipline grade; if admitted as a dependent, he was placed in the admission grade. Any child who falled to live up to the standard of any particular grade was, upon the recommendation of his supervisor and the approval of the Superintendent, demoted one or more grades.

There were to be certain privileges which went with each grade except that of discipline, where the 
child received no privileges. In the admission grade, the children were permitted to go swimming and to the picture show. In the Apprentice, the following privileges were added: recelving visits from members of their families and corresponding with members of their families. In the citizen's grade, in addition to the other privileges mentioned, the boys and girls were entitled to receive compensation (the allowance system previously described), membership, if qualified, in the Glee Club, Band, Inst1tution plays, swiming teams, baseball teams, etc., permission to leave the grounds on proper occasions, and to attend social gatherings.

A slight variation of this system was noted in the Superintendent's report for May, 1937, in which he described the division of the children into Honorcitizens, Citizens, and non-Citizens, depending upon their conduct and attitude. The length of time required for the child to become a citizen is thirty days clear record, to become an honor-citizen is sixty days clear record. The cash allowance pald to Honor-citizens at that time was twenty-five cents a month for those under twelve, thirtyfive for those twelve and thirteen, fifty for those fourteen and fifteen, and seventy-five cents for those sixteen and over.

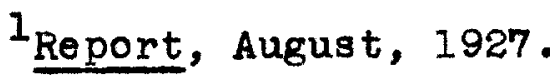

2 Ibid., May, 1937.
} 
That Mr. Bastin's ideal of discipline which he expressed as being "intelligent self-control" was effective is seen in the account of the influence of the Girl's Club, an organization among the older girls which they originated themselves. Their membership requirements stated that a girl must be fifteen years of age or older and an Honor Citizen; the $\mathrm{drew}$ up their own set of rules which held them to a rigid code of conduct and ethics. Of their own cholce they elected the principal of the school as their sponsor, thus creating a close tie between the girls and the administration. Mr. Bastin, recognizing the influence of this club on the other girls as well as the boys on the campus, recommended to the Board that a club room be fitted up in which these girls 1 could hold their moetings. A similar organization of importance more recent in origin is the Junior Council, composed of four Honor Citizens from each cottage, who make recommendations of names of their number who they think are ready for promotion to Honor Citizen. Another unlque feature of Ormsby village developed by $\mathrm{Mr}$. Bastin as a positive approach to character trainIng was the appointing of Sponsors for small groups of children. Each sponsor was assigned flve children; this group became a family substitute as far as that

$1_{\text {Report, March, } 1932 .}$ 
was possible. They ate together, went on shopping trips together, to the State Fair and other trips from the campus. The ideal was to have the sponsor take the place of the parent as far as that was possible, encouraging the child to share with the Sponsor both his joys and his sorrows. In order to make this as real as possible, the precedent was established that any confession made by a child to his sponsor would be held sacred in the strictest confidence. Not only was the sponsor under no obligation to the institution to reveal any sach confidences, but she was not permitted to do so without the consent of the child making the confession. A further duty of the sponsor was that of making the acqualntance of the parents or relatives of the child, strengthening the tie that bound the two together, interpreting them to each other in order that their reunion might be more easily accomplished at the time the child returned to his home. The effectiveness of these methods of positive discipline can be seen by any visitor to the institution. The boys and girls are seen doing things In a happy, natural way; the impression given is like that of a well-regulated boarding school.

In no place is the attitude toward discipline seen more clearly than in the treatment cottages where 
a small group of boys and girls is kept behind locked doors and windows. The purpose of these cottages was interpreted as being not for punishment, but to offer these boys and girls opportunity for spectal study and treatment until they could gain enough self-control to 11ve in the Village. "You can't treat a person when he runs away, so it is nocessary to lock them up in order to help them," the head house-mother remarked. The atmosphere of the cottages is in no sense repressive. On the day that the writer made a visit to the cottages, she noticed a set of rules posted on the bulletin board. The girls told her that they had organized a court among themselves which met three times a week. They had elected their own judge, jury, and policemen, and had made a list of crimes which would be tried in court. The crimes (their spelling) which they listed were:

1. Undecent exposure

2. Cussing

3. Cleaneness

4. Impudence

5. Disorderly conduct

6. Fussing

7. Disturbing the Peace

8. Paying debts

${ }^{1}$ Personal interview with Mrs. Bernice Dempsey, head house mother of Ormsby Village, July, 1943. 
9. Destruction of property

10. Theft

Changing Philosophy in Regard to the Child's

Relationship to His Parents

From the beginning of the House of Refuge, Mr. Caldwell found one of his most difficult problems to be the interference of parents in trying to secure the release of a child before he had been in the institution long enough to have benefited by the treatment. In 1877 he recommended an amendment to the c1ty charter wh1ch at that time gave the judge power to release boys and girls within ten days after they had been sent to the institution. He felt that parents used the Home as a sort of scarecrow to frighten their sons by having them committed, knowing they could secure their release again in a short time. He felt that this was one of the most serians problems he had to deal with in the institution; it had a bad influence on the boy because he entered with the feeling thet he would be released again within a few days Irrespective of his conduct. It was hard on the management because it left them in doubt as to where to place the boy in the shops. It was a costiy procedure to have the boy brought in, washed and provided with a new suit of clothes at the city's expense only to be 
released again in a few days time. The boy was worse for the experience, heving been encouraged in his evil ways by the interference of his family. The records shom that in many instances the boy was re-commltted after a short time, but "not until he had ruined the elothes that had been furnished him by the city." Mr. Caldwell clted some instances where boys refused to go with their parents when an effort was made to get their release, saying that more was done for them in the House of Refuge than the parents could do at home: they even went to the court and had themselves committed in order to remain in the institution.

Mr. Caldwell recommended that the power to release a boy from the institution be put in the hands of the Board exclusively, rather than in the hands of the judge. As an alternative to this recommendation, it was suggested that a boy be kept in jail for ten days until the court had determined whether or not he should be placed in the institution.

Because the home back-grounds of the children who were committed were often responsible for the child's bad habits, Mr. Caldwell felt that the interference of

\footnotetext{
${ }^{1}$ Munic1pal reports, 1877, p. 531.

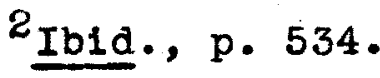

3 Ib1d., p. 533 .
} 
the parents often prolonged and sometimes retarded the good work that may have been started in the heart of the ch11d. He sald," I sometimes think it would be for the best interest of the child and the advantage of the institution to cut off all intercourse between parent and child for a considerable period of time after his reception into the school." 1 That this ald not represent his true thinking, however, is seen by the fact that he encouraged the boys to make things for their parents and frlends in the workshops, permitting each one on visiting day to give to his parents one article that he had made during the month. A few years later Mr. Caldwell broadened his view of the scope of the rork of the institution to include that of reforming the homes to which the children were to return. He felt it not only necessary to work toward making the home a better one for the child's return, but thought some supervision should be given the child in his home after his release.

The problem of premature dismissal was still a troublesome one in 1913 when Mr. Brown was Superintendent. He stated that the most disappointing sign to a growth of healthful conduct and group responsibility

$$
\begin{aligned}
& { }^{1} \text { Ib1d., 1895, p. } 94: \text {. } \\
& \text { Ibld., 1900, p. } 64 . \\
& { }^{3} \text { Ibld., 1903, p. } 192 .
\end{aligned}
$$


yas the tendency of parents to force premeture dismissals through sentimentalism alone. Two years later he rocommended that parents not be allowed to visit a child for one year after he had been commltted; if no improvement was seen in the child at the end of that time, visits were not to be permitted for another year. If there was still no improvement, the right to visit the child was to be permanently waived.

Soon after Mr. Bastin became Superintendent of the institution the question arose as to whether it would be posible for children to spend a day to a week with their parents or other relatives, particularly during the hollday season. Mr. Bastin, in his characteristic manner, weighed both sides of the question, listing the advantages and disadvantages of the proposition. He saw the following advantages:

1. Tles between the children and their parents would posibly be strengthened through permitting these visits.

2. The anticipation of such a visit would probably be an incentive to goo conduct while in the institution.

3. Small amounts of clothing would be purchased by the parents on some of these occasions, which otherwise might not be bought.

$$
\begin{aligned}
& 1_{\text {Ib1d., }} 1913, \text { p. } 575 . \\
& 2_{\text {Ib1d., } 1915, \text { p. } 421 .}
\end{aligned}
$$


However, the disadvantages which he listed seemed far to outweight the advantages in his mind. Among the disadvantages which he saw in such a procedure were:

1. The parents had no decent place for keeping the child at home, which was one of the causes of his being committed to the institution.

2. While on the visit the child would be overindulged with cheap food and candy which would be detrimental to his health.

3. The parents would lead the child to think that if he could just stay at home, their lives would be much happler, causing dissatisfaction in the child's mind and leading to disciplinary problems upon his return to the V111age.

4. Many of the relatives of the boys and girls had tuberculosis and other contagious diseases which the child might contract on his visit.

5. The parents gain a satisfaction from being able to have the children with them for short visits which compensate them for the chlld's absence and does not stimulate an effort to raise the standard of the home so thet the child could be returned permanently.

6. Those children who had no relatives to visit were made doubly dissatisfled at those times when the other children were permitted to go home for the holldays. 
7. Certain of the parents have such antagonistic attitudes toward all the forces of law that they are a bad influence on the children whenever there is any association with them.

That Mr. Bastin's thinking changed in this regard is seen by the fact that soon after that statement was made be established the system whereby a child was permitted to correspond with his parents, and have them visit him as soon as he had proved himself capable of self-disclpline and had become a citizen of the community. When he had showed sufficlent progress to become an Honor Citizen, he was permitted to visit his home at regular intervals. This gave the child an opportunity to begin makling an adjustment both to his family and to the conmunity from whlch he came for short periods at a time, looking forward to the time when he would become stabilized enough to return to his home permanently.

It was shortly after this time that several studies were made to discover the reciprocal attitudes of parents and adolescents where children were belng cared for away from home. It was discovered that the attitudes of the parent and child were influenced by the circumstances of placement, whether the child had been comitted by the court for delinquency, or because 
of the desertion, divorce, or lilness of the parents. The age of the child at the time of placement, and his relation to his parents prior to placement were also important factors. The conclusion was reached that regular, weekly visits tended to strengthen the bond between parent and child, while infrequent visits caused estrange1 ment. The relationship was kept on a more realistic basis when the child saw his parents often; a mutual idealization tended to arise when the perent and child were separated, and the return of the child to his home after a long absence without frequent contact with his parents was often dislilusionlng. A mistake sometimes made in an institution is that of protecting children from their own parents, making it easy for the child to overlook his parent's faults. When frequent opportunities are given for the parent to visit the child or the child to return to his home, the social worker who is studying the child is able to observe the effects on the child of the parent-child relationship. The mounting tension as the occasion approaches, the frightened

1 Joseph Bonapart, Reclprocal Attitudes of Parents and Adolescent Ch1ldren where these ChIIdren Are Being Cared for Away from Home, Procerdings of the National Conference of Social Work, 1930 (Chicago: University of Chicago Press), pp. 217, 218.

$2_{\text {Ethel Verry, Problems Facing Orphans, Proceedings }}$ of the National Conference of Social Work, I938 (Ch1eago: University of Chicago Press), p. 689. 
tenseness of the rejected, the ingratiating dependence of the indulged, the embarrasment of the child who is ashamed of his parents, are all valuable clues for the worker who is interested in helping the child to adjust to his family.

At the present time the parents of children at Ormsby village are permitted to visit their children as early after commitment, and as often as they like. Every effort is made by the workers to maintain the tie between the child and his family, while a like effort is made to rehabilitate the home in order that the child may return to his own people as soon as possible.

\section{${ }^{1}$ Lililan J. Johnson, Case Work with Children in} Institutions, Proceedings of the National Conference of Soclal Work, 1940 (Chicago: University of Chicago Press), p. 340 .

2 Interview with Miss Elizabeth Broecker, head of the Social Service Department of the L\&JCCH, August, 1943. 
CHAPTER V

EVALUATION OF THE WORK OF THE LOUISVILLE AND JEFFERSON COUNTY CHILDREN'S HOME 
CHAPTER V

EVALUATION OF THE WORK OF THE LOUISVILLE AND JEFFERSON COUNTY CHILDREN'S HOME

There are three factors that seem to be outstanding in the growth of the Louisville and Jefferson County Children's Home: first, the caliber of the men who have served as Superintendents, second, the quality of the persons who have served as Board members, and third, the loyalty and cooperation of the staff of house-mothers, social workers, teachers, psychologiats, doctors, min1sters, secretaries, and others who are employed to carry out the policies of the Superintendent and the Board. Among the cheracteristics needed for a good inst1tution, the first in importance is the quality of the personnel. People employed in this kind of work need to have a speolal aptitude for their job, to feel a sense of satisfaction in the work they are doing, and to have a sense of security in the tenure of the job. Fortunately, politics have nover played a part in the running of the Louisville and Jefferson County Children's Home due to the provision for having a bi-partisan Board;

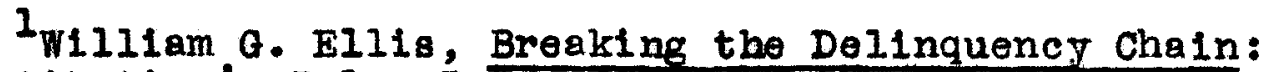
the Institution's Role, Procerdings of the Hational Conference of Social Work, 1941 (New York: Columbia University Press), p. 447 . 
the workers are chosen and kept because of the1r own ability, and not for political reasons. An increase in personnel is greatly needed, however, especially in the staff of social cese-workers. The case loads of the social workers employed by the institution are much too heavy to enable them to do anything approaching adequate social case-work. The average case-load of the workers is seventy where it should not exceed forty. As a consequence only those chlldren who make themselves troublesome enough to demand attention receive it; the quiet, more introverted child who may have special need for case-work treatment wilI tend to be overlooked because of the pressure of work of his social worker. While the salaries paid the workers are about equal to those pald by most of the other agencies in the city, they are less than those paid workers in similar institutions elsewhere, in that maintenance is not included. Consequently, there is a rapld turn-over of workers which is detrimental to the best interests of the child. The high national rating of the institution makes it easy for workers who have been successful at the Louisville and Jefferson County Children's Home to secure better pald positions elsewhere.

${ }^{1}$ Personal interview with Miss Elizabeth Broecker, Head Supervisor of the Sociel Service Department, August, 1943. 
Following the recommendation of the Osborne Report in $1940^{1}$ a second psychiatrist was employed by the inst1tution for half time. However, the problems that have necessitated the placing of most of the children in the Home are such as would require psychiatric service for almost every child committed, if that were possible. The establishing of a psychiatric clinic at the juvenile court gives special study to those outstanding cases seen in court; however, after those chlldren are placed in Chlidren's Center they are not assigned to a soclal worker until placement has been declded for them. One or two cases have been reported where mentaliy 111 children have suffered traumatic experiences while in the Center because of a lack of understanding by the Matrons of the need for special handling of such children. The employment of one or more psychiatric social workers at the Chlldren's Center rould be of benefit to the institution. While the psychiatrists and social workers are important in helping the child to adjust, the key persons in the Louisville and Jefferson County Chlldren's Home are the foster mothers and the cottage mothers. An effort is made to give training to the cottage mothers in under-

$$
\begin{aligned}
& \text { Iosborne Report, op. cit., p. } 137 \text {. } \\
& 2 \text { Personal interview with Mr. Pyne, head of the }
\end{aligned}
$$
Children's Center, Septemberl, 1943. 
standing the child's needs, and the reasons for difficult behavior problems, but it would be desirable if more training could be required of these key people. One of the responsibilities of the case-worker who places children in foster homes is to help interpret the child's needs to the foster mother as well as supervise her handling of the child. It is impossible with a case load of seventy chlldren elther to prepare the child adequately for placement or to supervise his adjustment in the foster home. War-time conditions in an industrial center such as Louisville, have increased the work of the foster home department tremendously. With a growing demand for foster home placements, there is a decrease of good homes available for use. Under such circumstances it is sometimes necessary to lower the standards of the homes in which chlldren are placed; this throws more responsiblitity on the social worker to supervise the homes and help the foster mothers, which again points to the need for more workers in this department.

The program of the institution is second in importance to the personnel. This should include opportunity for careful diagnosis, treatment possibilities which cover several flelds, and a kindly, serene atmosphere where a child's feers and uncertaintios can be adjusted.

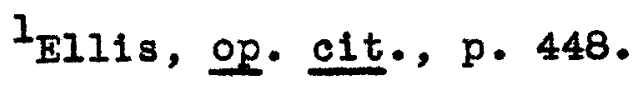


The purpose of Chlldren's Center is to afford a careful diagnosis of the child's needs before any plan is made for him. The employment of a psychiatrist at the Center to work with the most difficult cases is one of the outstanding features of the institution. The psychiatrist feels, however, that much more psychiatric work is needed than he is able to give and that additional poychiatric workers on the staff would be of great benefit. since the Foster Home Department, Ormsby Village and Rldgewood, are all included under one head it is possible to give careful attention as to whether the child would adjust better being kept in his own home, placed in a foster home or sent to the institution for treatment. Dr. Carstens thought that the facility with which children commlted to the Louisville and Jefferson County Children's Home may obtain the type of service neoded was one of the greatest assets of the organization. At a time when the foster-home budget was low and the institutions were not fllled to capacity, a regrettable practice was employed of taking a child out of a foster home where he was making a good adjustment and placing him in the

${ }^{1}$ Personal interview with Dr. Carl Whitaker, psychiatrist of the L\&JCCH, JuIJ, 1943.

${ }^{2}$ c. c. Carsten, Excerpts from the Report of the Loulsville and Jeffers on County Children ${ }^{+} \mathrm{s}$ Home made by the child Welfare League of America, Inc. (unpublished) February, 1934. 
institution in order to balance the budget, which is a weakness rather than a strength of centralization.

The program of activities within the institution has been described in previous chapters. A decided change of emphasis has been noted from viewing the institution as a purely industrial school to making it a place where educational opportunities in a broad sense have been avallable. The writer belleves that the pendulum has swung a bit too far in the interest of academic training to the neglect of vocational training. The vocational program is given a secondary place both as to organization, housing, equipment and personnel. Although it is extremely difficult to get good teachers for this department, the need for such training is important enough that more effort might be made to put it on a basis which is as good or even better than the academic. A good vocational building with adequate equipment would make 1t easier to secure and keep qualified teachers. Three vocational subjects receive Federal ald under the SmithFughes Act, automobile mechanics, building trades and home economics. Other vocational training is given in painting, laundry, kitchen and bakery, carpentry, electricity, farming, dalrying, poulty raising, gardening

Iosborne Report, op. cit., p. 100. 
of vegetables and flowers, care of lams, green-house, canning, woodwork and telephone operation. Better use could be made of many of these learning experiences than is made, however, if efficlency of operation were sacrificed to the training of boys and girls. The superintendent says that it is difficult to find a person who is interested in these activities as a teaching project rather than in having the job well done, but much would be galned by the boys and girls if such teachers could be procured.

The need for greater opportunities for vocational training is especialiy acute at Ridgerood. More space is needed for this department, better equipment and sk1lled teachers. The Osborne: Report in 1940 described the conditions at Ridgewood as being drab and uninspiring. The unkempt appearance of the grounds and bulldings was more noticeable because of the contrast between the bleakness found bere with the home-like and orderly appearance of Ormsby Village. Of more signiflcance than the appearance of the buildings, however, was the fact that the personnel of the division was not as well

${ }^{I}$ Interview with Mr. Bastin, June, 1943.

${ }^{2}$ Interview with Mrs. Bernard Marshall, member of the Board for the past elght years, September, 1943. 
qualified and competent as the Ormsby Village Staff. The writer recelved a very different impression on visiting Ridgewood on August-thirty-first, 1943, however. The bulldings were all in excellent condition, the dormitories home-like, the school rooms and dining room bright and attractive. Many of the workers were away, as school was not in session at the time; but the ones to whom she talked seomed to be persons of warmth and understanding In regard to the problems of their positions. The head of the institution had his master's degree in social adminlstration. The recommendation for the building of a gymasium and swimming pool at Ridgewood, when carried out, will give proper space for vocational training which is now lacking. At the present time the home economics department is having to use the iarge dining room and kitchen for class room purposes. A spectal unit should be included in this department simflar to the one at Ormsby Village where the girls can be taught the proper manner of prepering and serving a meal, of being hostess and of taking care of equipment. The need for a swimming pool at Ridgewood is being met temporarily by taking the boys and girls into Louisville to a pool once a week.

IOsborne Report, op. cit., p. 132. 
Another branch of the institution where more profit could be gained by stressing vocational training rather than academic is in the Children's Center. Presumably the children are placed in the center for only a few days whilo their cases are being studied to determine what is the best plan to be made for the child. Elghty-five per cent of the chlidren who come to the center have been having difflculty with their school adjustment. At a time of inner turmoil when the child is uncertain what the future holds for him, little benefit would be galned by trying to help him concentrate on academic subjects. Mr. Pyno reported that almost without exception the mothers with whom he talked sald that their boys liked to hammer and saw, or do some kind of manual work. If several good work shops such as radio, painting, wood-work, sewing, could be set up in the roons in the basement more, would be accomplished with these emotionally disturbed boys and girls during the stay at the Center than by trying to get them to concentrate on reading, writing and arithmetic. .

It has been said that presumably the boys and girls who are placed in the chlidren's center remain there for only a few days. Unfortunately this is not the

Interview with Mr. Pyne, head of the Center, August $31,1943$. 
case, however. Mr. Pyne told of one girl who had been kept there for six months recentiy, and a family of five chlldren who had been there for a hundred and thirty-one deys, and were still there. It is impossible to build a program that would be suitable for a short time placement and also adequate for such a long stay. Mr. Pyne believes that if these children had been under the supervision of some case-working agency, such a condition would not have occurred. Because the probation officers are so pressed with work, they often place a child in the Center and then forget about him without making sufficlent effort to work out some other plan for him.

We now turm to the third characteristic of a good institution, that of having a plant that is adequate for the needs of the children. The bulldings and grounds of the Loulsville and Jefferson County ChIldren's Home are kept in excellent condition. The institution owns four hundred and twenty acres of land, and leases a hundred and seventy more. The bulldings and adjacent grounds occupy seventy-five acres, the remainder is used for farming purposes. Eleven cottages with individual normal capacity of twenty-five to thirty, provide the housing for the children at Ormsby Village. Ridgewood has two cottages, with one administration building which has dormitory

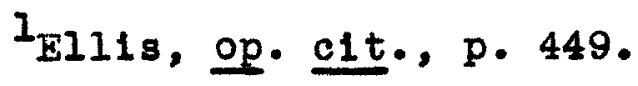


space on the second floor. These cottages have a homelike atmosphere in the living rooms, but the sleeping quarters are large barracks with no opportunity for privacy. Individual lockers and dressing tables for the girls, which they are permitted to decorate after their orn tastes help to put a personal touch to the sleepling quarters, however. Additional bulldings are recommended, which should include two discipline cottages, residences for employees, a vocational bullding, an addition to the auditorium, and a gymnasium and swimming pool at Ridgewood.

Having considered the personnel, the program and the plant of the Louisville and Jeffergon County Children's Home, we turn to the question of the function of such an institution and how this Home meets thos e requirements. This function has been described as being four-fold: its primary purpose is to furnish training and treatment for those children who give evidence of serious maladjustment. A second important function is to serve as a center of research into the causes of delinquency and the effectiveness of treatment plans. Thls should include an effort to discover why the child got into the difficulty 
which brought him to the institution, what the factors were behind his particular offense, and what his response was to the treatment which was given. A third function is that of a diagnostic center for chlldren who need speclal study before any decision is made as to the type of treatment needed. The fourth function of such an institution is that of providing training for professional workers on an internship basis. The first and third functions have already been described in this thesis. The fourth is fulfilled in part in the cooperation with the Graduate Division of Social Administration of the University of Louisville in giving supervision to its students in social case-work in this fleld. The second function listed, that of serving as a center of research into the causes of delinquency and the effectiveness of treatment plans, is one that noeds to be stressed farther. The Osborne Report makes such a recommendation:

Because Ormsby Village is so progressive and so unique in many ways already indicated it would seem desirable for it to have facilities for the constant scientific study and evaluation of various phases of its treatment program. Continued encouragement should be given responsible students for the carrying out of such research and some thought might also be given the possibility of establishing a small staff of research workers..... It is therefore recommended that a trained research worker be appointed to the staff to formulate and carry through research projects and to gather and interpret statistical data. 2

$$
\begin{aligned}
& 1_{\text {El11s, op. c1t., p. } 447 .} \\
& 2_{\text {Osborme Report, op. c1t., p. } 136 .}
\end{aligned}
$$


The citizens of Loulsville and Jefferson County have felt great satisfaction in the evaluations of the Home that have come from many sources.

In $1931 \mathrm{Dr}$. H. E. Barnard, D1rector of the White House Conference on Child Health and Protection, Weshington, D. C., writing to the editor of the Courler-Journal said, "I think ormsby village is doing the best work of its kind of any similar institution in the country." He added that $\mathrm{Mr}$. Bastin was doing the job society had given him far more effectively than jails or reformatories or the usual type of institution where children we re supposed to be rebullt, but were actually denled the opportunity for normal life. He considered the service it was giving to Louisville and Jefferson County to be "in every way admirable." 1

The following year Mr. Bastin was notified by Mr. Clarence E. Pickett, Executive Secretary of the Americ an Friend's Service Commission of Philadelphia, that Ormsby V1llage had been selected by Mr. Henry van Etten, a French Quaker who visited America for the purpose, as one of the four outstanding institutions of its kind in America. Mr. Van Etten had been active in organizing work in French prisons, and had visited America to observe the type of

\section{${ }^{1}$ Letter to the managing editor of the courier-} Journal, copled in the Superintendent's report, October 12, 1931. 
work being done in this country. Only one other of the institutions which he recommended to the French People gave care to chlldren, the other two being institutions for adults. 1

Soon after the consolidation of the Industrial School and the Parental Home the Russell Sage Foundation instructed Mr. Hastings H. Hart, consultant in Delinquency and Penology, to make a study of the institution. Mr. Hart felt that extraordinary improvement had been made since the consolidation of the two schools "which put the Institution in the front rank of schools of its class, not only in the South but in the whole United States." He sensed a oneness of purpose in the Superintendent, the Board, the Staff and the pupils which tended to send out young people who would be able to take their plece in soclety as good citizens, workers, and home-makers. Mr. Hart was impressed by the fact that a man who had been the head of an adult prison could have the optimism and vision of reclaiming neglected and difficult boys and girls that was characteristic of Mr. Bastin. He felt that $\mathrm{Mr}$. Bastin had taken his place in the same class with such superintendents as Howe of Ohio and New York; Adams of Ohio and Illinois; Charlton of Indiana; Derrick

$1_{\text {Report, May } 5,1932 .}$ 
of Callfornia and New Jersey; Faulkner of Maryland and New York; and Brother Barnabas of New York.

It has been the policy of the institution to have studies made of its work at rather frequent intervals and to follow as far as practical the recommendations of the findings. The next important study to be made was by Dr. C. C. Carstens, Executive Director of the Child Welfare League of America, In 1934 at the request of the institution in order to ascertain if it would be possible to cut the budget of the institution without sacrificing the work that was being done. After Dr. Carstens had made a careful study of all phases of the work of the institution, he made the following estimate:

Ormsby Village, whose development I have followed for ten years, is one of the best managed and most efficient children's institutions in the country.... There are but few institutions in the United States in the same class with it.2

Dr. Carstens observed further that the services rendered by the Loulsville and Jefferson County Children's Home were those done by Children's Bureaus in many parts of the country. He felt thet it was well to keep in mind the use of the institution as a children's bureau so that various public services to children in the county may be

${ }^{1}$ Hastings Hart, "Ormsby Village, the Louisvilie and Jefferson County Children's Home" (unpublished), 1927.

$\dot{z}_{C}$. C. Carsten, "Excerpts from the Report of the Louisville and Jefferson County Children's Home made by the Child Welfare League of America, Inc." (unpublished, February, 1934. 
concentrated as far as posible under one management. The most recent study of the institution made by a national organization is the Osborne Report, made in 1940. This study and the one made by Hastings Hart were made in the interest of the organizations making the report; the study made by Dr. Carstens in 1935 was made at the request of the Louisvilie and Jefferson county Children's Home to ascertain whether it would be possible to make cuts in the budget without injuring the rork of the institution. The Osborne Association in making a nation-wide survey of institutions for delinquent juveniles, made the following statement in regard to the Louisville and Jefferson County Children's Home:

Among the organizations and institutions for delinquent juveniles thus far studied by the Association it stands foremost as one that has developed a program of especially high standards along professional and humanitarian lines.

Here at Ormsby Village is an institution so distinguished for its values in citizenship building that it would be no surprise to the Association if it should rank as one of the best to be covered in this nation-wide survey.1

Despite the fact that the institution has been recognized by national authorities as being one of the best of 1ts kind in the country, the citizens of Loulsvilie and Jefferson County know little of 1ts history or its

$$
\text { IOsborne Report, op. c1t., p. } 128 .
$$


program. The institution would profit if a closer tie-up could be achleved between the Louisville and Jefferson Children's Home and the community which it serves. The Christian Fellowship, sponsored by the Federal Councll of Churches, is one instance where this kind of effort has been successful. The Junior Red Cross at the Home did such excellent work that it was used for exhibition purposes in all the city schools, which is another example of success in this Iine. The Ormsby Village Boy scout troop made history in the summer camp at the Covered Bridge Scout Camp in the summer of 1943, winning top honors in all events and being proclalmed the best troop in the camp.

In recent years the annual report submitted by the Superintendent to the Mayor has been in the nature of a business report only. The writer feels that if an additional report were made in which some of the significant changes within the administration of the institution were Included, and a few such items as the ones given above, a better understanding of the pollcles of the institution would be available to those particularly interested in child welfare in Louisville and Jefferson County.

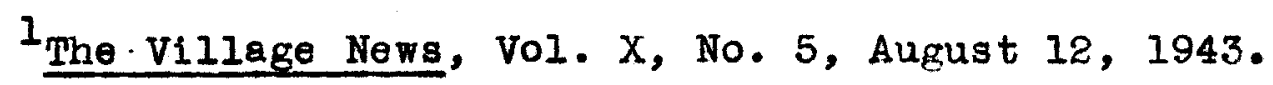


BIBLIOGRAPHY 


\section{BIBLIOGRAPHY}

\section{Books}

Breckenridge, Sophonisba B. Public Welfare Administration in the United States Select Documents. 2d ed. Chicago: The University of Chicago Press, 1938.

The Delinquent Child. White House Conference on Child HeaIth and Protection. New York: Century Co., 1932 .

Furfey, Paul H. Social Problems of Childhood. New York: Macmillan CO., IgZ9.

Handbook of American Institutions for Delinquent Juveniles. Hew rork: The ogbome Association Publishers, 1940. lst ed. Vol. II.

History of the Ohio Falls Citles and Counties, 1778-1882. Vol. I. Cleveland, OhIo: L. A. WIIIIams and Co., 1886 .

Jamison, A. T. The Institution for Children. Columbia, S. C.: Baptist Book Depository, 1926.

Mangold, George B. Problems of Child Welfare. Revised edition. New York: Macmilian Co., I924.

Memorial History of Louisville. Eidted by J. Stoddard Johnston. Chicago: American Blographical Publishing Co., 1896.

Thurston, Henry W. The Dependent Ch1Id. Nen York: Columbia University Pres3, 1930.

\section{Reports}

Annual Communication of the Mayor and Reports of the Departments of the city of Louisville for the Year Ending December 31, 1866. Loulsville: Bradley and Gilbert, $\$ 867$.

Annual Report of the Trustees of the Almshouse of the City of Loulsville for the Year Ending March 10, 185\%. Loulsville: HuII and Bros., 1858. 
Monthly Reports of the Loulsville and Jefferson County ChIldren's Home, 1923-1943.

Munic1pal Reports, 1867-1915. Loulsville, Kentucky.

Newspaper Clippings

Daily Courier. January 18, 1854; January 28, 1854.

\section{MISCELLANEOUS}

Continuity of Case Work Service--Individualization in the Institutional Setting. ChIld Welfare League

Industrial School Gem, November, 1907.

Laws Creating the Loulsvilie and Jefferson County Children's Home. Ormsby VIIlage Press, 193\%.

Ilpitz, Irving M. "Louisvilie, Kentucky Home for the Aged and Infirm". Unpubilished M.S.S.A. Dissertation, Graduate Division of Social Administration, University of Loulsville, 1942 .

Louisville City Directory. Loulsville: Richard W. Ot1s, 1832 .

Manual for Cottage Mothers in Institutions. Published by Child Welfare League of America.

Proceedings of the Conference of Charities and Correction 1874-1916.

Proceedings of the Conference on the Care of Dependent Chlidren held at Vashington, D. C., January 25, 26, 1909. Washington: Government Printing of $1 \mathrm{ce}, 1909$.

Proceedings of the National Conference of Social Work 1911-1942.

Slingerland, w. H. Child Welfare in Louisville. New York: Child Felfare Leggue, I9I9.

Stendards of Foster Care for Children in Institutions. New York: ChIId WeIfare League, 1937.

Weber, Margaretta. Work1ng w1 th Delinquent and Dependent Children in the Same Institution. Ormsby VIIlage Press, 1935. 